\title{
Canadian Legal Ethics: Ready for the Twenty-First Century at Last
}

Adam M. Dodek

Follow this and additional works at: http://digitalcommons.osgoode.yorku.ca/ohlj

Part of the Legal Ethics and Professional Responsibility Commons Article

\section{Citation Information}

Dodek, Adam M.. "Canadian Legal Ethics: Ready for the Twenty-First Century at Last." Osgoode Hall Law Journal 46.1 (2008) : 1-49. http://digitalcommons.osgoode.yorku.ca/ohlj/vol46/iss1/1

This Article is brought to you for free and open access by the Journals at Osgoode Digital Commons. It has been accepted for inclusion in Osgoode Hall Law Journal by an authorized editor of Osgoode Digital Commons. 


\title{
Canadian Legal Ethics: Ready for the Twenty-First Century at Last
}

\begin{abstract}
This article analyzes the transformation in the scholarship of legal ethics that has occurred in Canada over the last decade, and maps out an agenda for future research. The author attributes the recent growth of Canadian legal ethics as an academic discipline to a number of interacting factors: a response to external pressures, initiatives within the legal profession, changes in Canadian legal education, and the emergence of a new cadre of legal ethics scholars. This article chronicles the public history of legal ethics in Canada over the last decade and analyzes the first and second wave of scholarship in the area. It integrates these developments within broader changes in legal education that set the stage for the continued expansion of Canadian legal ethics in the twenty-first century. Reprinted by permission of the publisher.
\end{abstract}

\section{Keywords}

Legal ethics; Law--Study and teaching; Canada 


\title{
Canadian Legal Ethics: Ready for the Twenty-First Century at Last
}

\begin{abstract}
ADAM M. DODEK *
This article analyzes the transformation in the scholarship of legal ethics that has occurred in Canada over the last decade, and maps out an agenda for future research. The author attributes the recent growth of Canadian legal ethics as an academic discipline to a number of interacting factors: a response to external pressures, initiatives within the legal profession. changes in Canadian legal education, and the emergence of a new cadre of legal ethics scholars. This article chronicles the public history of legal ethics in Canada over the last decade and analyzes the first and second wave of scholarship in the area. It integrates these developments within broader changes in legal education that set the stage for the continued expansion of Canadian legal ethics in the twenty-first century.
\end{abstract}

Cet article analyse la transformation que subit la connaissance profonde de la déontologie juridique, transformation qui s'est produite au Canada au cours de la dernière décennie, et trace un programme pour la recherche future. L'auteur attribue le récent essor de la déontologie juridique canadienne, en tant que discipline académique, à un certain nombre de facteurs s'influençant l'un l'autre : réaction aux pressions externes, initiatives au sein des professions juridiques, modification de la formation canadienne aux métiers juridiques, émergence d'un nouveau cadre de juristes spécialisés en déontologie juridique. Cet article relate l'histoire publique de la déontologie juridique au Canada durant la décennie écoulée. Il analyse la première et la seconde vagues de connaissance profonde dans ce domaine. II intègre de tels développements à des mutations plus amples sur le plan de la formation juridique, lesquelles préparent le terrain à l'expansion continue de la déontologie juridique canadienne, qui se poursuivra au XXlè siècle.

* Visiting Scholar, Osgoode Hall Law School, York University and Fellow, Centre for Professionalism, Ethics and Public Service, University of Toronto. Effective 1 July 2008, Associate Professor, Faculty of Law, University of Ottawa. Thank you to Bruce Elman, Lorne Sossin, and Alice Woolley for taking the time to discuss some of the issues in this article and to my fellow teachers in Osgoode's inaugural Ethical Lawyering in a Global Community course (2007-08): Professors Trevor Farrow, Janet Mosher, and Robert Wai. Some of the ideas in this article grew out of the many hours of discussion we had in creating and preparing that course. It was and is a worthwhile and exciting endeavour. Thank you also to Laura Johnson, University of Toronto J.D. Candidate, Class of 2009, for providing invaluable research assistance. 


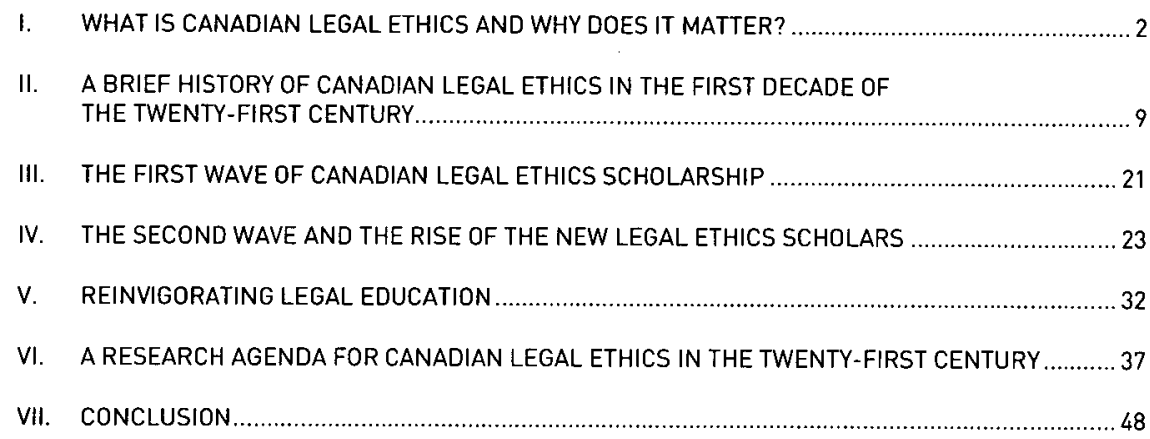

\section{WHAT IS CANADIAN LEGAL ETHICS AND WHY DOES IT MATTER?}

NEARLY A DECADE AGO I described the bleak state of legal ethics scholarship in Canada. 'This void surely was not for want of opportunity. It would have been difficult then, or even a decade or two before, to dispute the existence of a subject matter identified as "Canadian legal ethics." Legal ethics is not a postmodern academic school like Critical Legal Studies nor is it a result of new developments like Law and Internet or Law and Biotechnology. Canadian legal ethics has existed for decades, at least since there were Canadian lawyers, and perhaps earlier. However, for the most part, the academy has simply ignored it. It was, in short, a subject in search of scholarship. ${ }^{2}$

At the time that I wrote that article, I welcomed the publication of a new monograph by Allan Hutchinson of Osgoode Hall Law School ("Osgoode" or "Osgoode Hall"), ${ }^{3}$ commenting facetiously that it reflected the trend in Canadian legal ethics of publishing one book per decade. In this respect, Canada compared quite unfavorably to other jurisdictions. The United Kingdom was witnessing a burst of scholarly activity about legal ethics: several

1. See Adam M. Dodek, “Canadian Legal Ethics': A Subject in Search of Scholarship” (2000) 50 U.T.L.J. 115 [Dodek, "A Subject in Search of Scholarship"].

2. Ibid.

3. See Allan C. Hutchinson, Legal Ethics and Professional Responsibility (Toronto: Irwin Law, 1999). The book is now in its second edition. See Allan C. Hutchinson, Legal Ethics and Professional Responsibility, 2d ed. (Toronto: Irwin Law, 2006). Unless otherwise noted, all references are to Hutchinson's second edition [Hutchinson, Legal Ethics]. 
books and a new journal devoted to the subject, appropriately titled Legal Ethics. With the United States, the contrast was even starker. After Watergate, legal ethics-often referred to as "professional responsibility"-became a compulsory subject in American law schools, resulting in a torrent of creative scholarship. In Canada, the situation was far less vibrant. At the turn of this century, one of the most cited Canadian texts remained Mark Orkin's 1957 classic, ${ }^{4}$ which has only recently been usurped by Gavin MacKenzie's treatise, ${ }^{5}$ now in its fourth edition.

While the scholarship of Canadian legal ethics still has far to go in order for it to become a truly vibrant discipline, it has grown significantly over the last decade as the profession and the academy have embarked on some interesting and exciting projects. Canadian legal ethics can no longer be described as a subject in search of scholarship; Canadian scholars have now begun to seek out answers to some of the most vexing ethical issues facing lawyers and our profession. For the first time, the foundations are in place for Canadian legal ethics to develop as a scholarly discipline.

The recent growth of Canadian legal ethics as an academic discipline can be attributed to a number of factors: a response to external pressures, initiatives within the legal profession, changes in Canadian legal education, and the emergence of a new cadre of scholars prioritizing legal ethics scholarship. These are not isolated factors but rather are overlapping and mutually reinforcing. This article chronicles the development of Canadian legal ethics over the last decade, analyzes its continuing challenges, and suggests some possible research agendas for the next stages in Canadian legal ethics development in the twenty-first century. Before I embark on this review and analysis, one might ask why any of it matters.

Developing a strong and sustained scholarship of legal ethics in Canada is imperative for a number of reasons. Canadian lawyers have been concerned

4. Mark M. Orkin, Legal Ethics: A Study of Professional Conduct (Toronto: Cartright \& Sons, 1957) [Orkin, Legal Ethics].

5. Gavin MacKenzie, Lawyers and Ethics: Professional Responsibility and Discipline, 4th ed. (Toronto: Carswell, 2006), originally published in 1993. Two years before my 2000 article, Dodek, "A Subject in Search of Scholarship,"supra note 1, Harry Arthurs described the lack of Canadian scholarship in even starker terms. See H.W. Arthurs, "Why Canadian Law Schools Do Not Teach Legal Ethics" in Kim Economides, ed., Ethical Challenges to Legal Education of Conduct (Oxford: Hart Publishing, 1998) 105 at 109 (noting the "almost total absence of a body of domestic scholarly literature on the subject"). 
about ethics going back as far as the creation of the organized profession in various jurisdictions. The profession's concern over its ethics and those of its members was given formal and public form through the adoption of codes of ethics, beginning with the Canadian Bar Association (CBA)'s Canon of Legal Ethics in $1920 .^{6}$ The motives and ramifications of this movement are themselves uncertain, subject to their own specific academic inquiry. ${ }^{7}$ However, the profession's formal claim to ethics has been constant; the bar has always proclaimed that law is not merely a trade but rather a profession, which entails a higher calling in pursuit of the public interest. Examining this claim has motivated whatever scholarship of legal ethics has existed in Canada and will continue to do so for as long as there are lawyers.

More recently, additional factors-both within the legal profession and, more generally, within the professional world-have made the study of legal ethics more pressing. In the 1970s, the American public and the legal profession faced a crisis of ontological proportions in the Watergate scandal, "in which lawyers were placed under national scrutiny and obliged to reconsider the legitimacy of their professional practices and norms of conduct." ${ }^{8}$ The American Bar Association responded by making the teaching of legal ethics mandatory for all accredited law schools. Subsequent crises involving lawyers, such as the collapse of the savings and loan industry in the 1980 s, the nearcollapse of Salomon Brothers in the early 1990s, and of course the fall of Enron in the early years of this decade, served to continuously reinvigorate debateacademic and public - over lawyers' ethics south of the border. Canada has not endured scandals of the same magnitude as the United States; however, this does not make the need for academic ethical inquiry any less pressing.

On a more general level, we value professional ethics differently than we did twenty or even ten years ago. ${ }^{10}$ We need only think of the rise of bioethics

6. Canadian Bar Association, Canons of Legal Ethics (Ottawa: Canadian Bar Association, 1920)

available in W. Wesley Pue, "Becoming 'Ethical': Lawyers' Professional Ethics in Early

Twentieth Century Canada" (1991) 20 Man L.J. 227 at 234-37 [Pue, "Becoming 'Ethical"].

7. See e.g. Pue, "Becoming 'Ethical," ibid.

8. Hutchinson, Legal Ethics, supra note 3 at 5-6.

9. On corresponding crises in the Canadian legal profession see generally ibid. at 2-5.

10. I leave aside the whole question of the gendered and racial conception of legal ethics and professionalism, itself a very fertile field of ethical inquiry. See e.g. Constance Backhouse, "Gender and Race in the Construction of 'Legal Professionalism': Historical Perspectives" 
in the medical field and corporate social responsibility and corporate governance in the business field as leading indicators of these changes. In attention to ethics, the Canadian legal profession and the legal academy have fallen behind their medical and business counterparts. Ethics courses have become part of the curriculum of those professional schools, helping to develop a common understanding that the academic study of ethics is a legitimate if not a necessary scholarly undertaking, connected to the instruction of new professionals in these and other fields. ${ }^{11}$ The growth of professional ethics in other disciplines legitimizes legal ethics as a field of academic inquiry, and makes its work more urgent, as the academic study of legal ethics lags behind several of its professional counterparts.

The forces of globalization are making ethical issues for lawyers and the legal profession more apparent and are generating new issues. When the practice of law was more localized and the legal profession more homogenized, ethical inquiry could be more easily ignored because ethical behaviour was determined largely by resorting to a common legal culture, expressed in written and unwritten codes of conduct. However, the national and international mobility of legal practice brings existing understandings of ethics into a comparative perspective, providing the opportunity for reflection on the basis for such ethics, as well as creating conflicts at times between local or prevailing ethical understandings and those in other jurisdictions. This necessitates both ethical inquiry and the creation of a new field of "conflicts of legal ethics" analogous to conflict of laws in private international law.

Given the evolving nature of legal ethics, "Canadian legal ethics" could mean several different things. A strong positivist strain permeates legal ethics in

(Paper Presented at the First Colloquium on the Legal Profession, Faculty of Law, University of Western Ontario, London, Ontario, 20 October 2003), online: Law Society of Upper Canada (LSUC) <http://www.lsuc.on.ca/media/constance_backhouse_gender_and_race.pdf> [Backhouse, "Gender and Race in the Construction of 'Legal Professionalism"'].

11. On mandatory ethics instruction for medical students see Richard Devlin, Jocelyn Downie \& Stephanie Lane, "Taking Responsibility: Mandatory Legal Ethics in Canadian Law Schools" (2007) 65 The Advocate 761 at 761 [Devlin, Downie \& Lane], citing Lisa S. Lehmann et al., "A Survey of Medical Ethics Education at U.S. and Canadian Medical Schools" (2004) 79 Acad. Med. 682 at 683. Devlin, Downie \& Lane also note that the Canadian Council for Accreditation of Pharmacy Programs requires content in ethics and professionalism. Similarly the relevant accounting bodies have mandatory pervasive ethics instruction requirements. See Devlin, Downie \& Lane at 773. 
Canada, which views the field as simply encompassing the ethical rules of lawyering, contained for the most part in the CBA's Code of Professional Conduct $^{12}$ (and its provincial counterparts) as well as in traditional areas of law, such as tort, contract, and agency, among others. While the issues in the codes of conduct provide excellent fodder for analysis and debate, legal ethics consists of much more than "the law governing lawyers." ${ }^{13}$ To begin with, the prominence or the relevance of such codes is itself a hotly contested issue in legal erhics, Canadian and otherwise. ${ }^{14}$ In addition, many of the codes are silent on some of the most interesting and most debated issues in Canadian legal ethics: lawyers' duties respecting physical evidence of a crime, sex with clients, and corporate fraud, among others. Legal ethics is concerned not only with the positivist inquiry of what is, but very much with the normative inquiry of what ought to be. ${ }^{15}$

12. Canadian Bar Association, Code of Professional Conduct, rev. ed. 2004 and 2006 (Ottawa: Canadian Bar Association, 2006) [CBA, Code of Professional Conduct].

13. The "Law Governing Lawyers" is one aspect or approach to legal ethics. See Susan Martyn, Lawrence Fox \& W. Bradley Wendel, The Law Governing Lauyers: National Rules, Standards, Statutes, and State Lauyer Codes, 2007-08 Statutory Supplement (Waltham, MA: Aspen Publishers, 2007).

14. In Canada see e.g. Hutchinson, Legal Ethics, supra note 3 at 13-17; Margaret Ann Wilkinson, Christa Walker \& Peter Mercer, "Do Codes of Ethics Actually Shape Legal Practice?" (2000) 45 McGill L.J. 645 (results of the study indicated that the majority of participant-lawyers did not use Ontario's Professional Conduct Handbook as a means of solving ethical problems); Joan Brockman, "The Use of Self-Regulation to Curb Discrimination and Sexual Harassment in the Legal Profession" (1997) 35 Osgoode Hall L.J. 209; Gavin MacKenzie, "The Valentine's Card in the Operating Room: Codes of Ethics and the Failing Ideals of the Legal Profession" (1995) 33 Alta. L. Rev. 859; Pue, "Becoming 'Ethical," supra note 6 (describing the adoption of professional codes as a mechanism by which the legal profession could justify its special privileges and roles to the public); and John Honsberger, "Legal Rules, Ethical Choices and Professional Conduct" (1987) 21 L. Soc'y Gaz. 113. Regarding the United States see Samuel J. Levine, "Taking Ethics Codes Seriously: Broad Ethics Provisions and Unenumerated Ethical Obligations in a Comparative Hermeneutic Framework" (2003) 77 Tulane L. Rev. 527; J. Ladd, “The Quest for a Code of Professional Ethics: An Intellectual and Moral Confusion" in Geoffrey C. Hazard, Jr. \& Deborah L. Rhode, Professional Responsibility and Regulation, 2d ed. (New York: Foundation Press, 2006) 105; Deborah L. Rhode, "Why the ABA Bothers: A Functional Perspective on Professional Codes" (1981) 59 Texas L. Rev. 689; and Deborah L. Rhode, ed., The Legal Profession: Responsibility and Regulation, 2d ed. (Westbury, NY: Foundation Press, 1988).

15. An excellent statement of the possible scope of inquiry for legal ethics is found on the homepage of the British journal Legal Ethics: 
Legal ethics consists of "macro-ethics" as well as "micro-ethics." Macroethical inquiries address systemic issues within the legal system and the legal profession, such as access to justice, public interest, diversity within the profession, and independence of the bar. Micro-ethics focuses on the ethical issues that confront individuals within the legal system. Micro-ethics-issues such as conflicts of interest, confidentiality, and client perjury-occupy most of the ethical space in discussions about legal ethics, but the macro-ethical issues go to the heart of the legitimacy of the legal profession and the legal system. In addition, legal ethics should be concerned about all of the actors in the legal system: lawyers, judges, clients, self-represented litigants, witnesses, jurors, court administrators, and the media, as well as those outside the formal boundaries of the profession who also provide legal services, such as notaries, immigration consultants, Aboriginal caseworkers, and-dare I suggest-paralegals. ${ }^{16}$

Canadian legal ethics must also attempt to situate ethical issues within a distinctly Canadian context. ${ }^{17}$ A Canadian scholarship of legal ethics must further seek to identify and articulate uniquely Canadian aspects of our legal system and the practice of lawyering in our country. These distinctions may be structural

The journal is intended to provide an intellectual meeting ground for academic lawyers, practitioners and policy-makers to debate developments shaping the ethics of law and its practice at the micro and macro levels. Its focus is broad enough to encompass empirical research on the ethics and conduct of the legal professions and judiciary, studies of legal ethics education and moral development, ethics development in contemporary professional practice, the ethical responsibilities of law schools, professional bodies and government, and the jurisprudenrial or wider philosophical reflections on law as an ethical system and on the moral obligarions of individual lawyers.

Legal Ethics, online: <http://www.hartjournals.co.uk/le/>.

16. In 2006, the Government of Ontario enacted legislation to regulate paralegals under the LSUC's oversight. See Bill 14, Access to Justice Act, 2nd sess., 38th Leg., Ontario, 2006 (assented to 19 October 2006), S.O., 2006, c. 21, Sch. B; Ministry of the Attorney General, Ontario, News Release/Comuniqué "New Era Begins with Pathbreaking Paralegal Regulation" (17 November 2006), online: Ministry of Attorney General <http://www.attorneygeneral. jus.gov.on.ca/english/news/2006/20061117-paraleg-EN.pdf; and Law Sociery of Upper Canada, "Paralegal Regulation," online: <http://www.lsuc.on.ca/paralegalss. In more narrow terms, Justice Major defined the ethical standard that the legal profession must adhere to as "not only concerned with the immediate and narrow relationship between the lawyer and the client, but with the wide issue of the place of a profession in society and its corresponding obligation to that society as a whole." Justice J.C. Major, "Lawyers' Obligation to Provide Legal Services" (Address to the National Conference on the Legal Profession and Professional Ethics, 9 June 1994), (1995) 33 Alta. L. Rev. 719 at 719.

17. Hutchinson, Legal Ethics, supra note 3 at 7 (noting that his theory of legal ethics emphasizes "the Canadian predicament"). 
(such as the impact of federalism, articling, discipline by law societies, and a unitary legal profession, among others) as well as normative or cultural (such as the values of multiculturalism and diversity, ${ }^{18}$ or the ethic of "zealous representation.") 19

One theme of this article is that there are multiple accounts of legal ethics in Canada and that significant disparities exist between them. A public account of Canadian legal ethics emphasizes the issues that the public sees, mostly through reporting in the popular press. The legal profession's account of legal ethics is reflected by the activities of law societies and legal associations, most notably through codes of conduct and discipline, but also through other activities such as task forces, public advocacy, and litigation. Sociological accounts examine what is actually happening within the profession and historical accounts analyze what has happened in the past. We can also conceive of the body of collected academic work on Canadian legal ethics as the scholarly account of the subject. As will be apparent throughout this article, significant gaps exist between the different accounts. In this article, I focus on the accounts of the public and the legal profession and compare their contents to the developing scholarly account of Canadian legal ethics.

In addition to the introduction, this article consists of six parts. In Part II, I briefly review the history of legal ethics in Canada over the last decade, focusing on the public account and the legal.profession's account. This part provides a basis for analyzing the scholarly developments during this period, as well as for

18. See e.g. Rosemary Cairns Way, "Reconceptualizing Professional Responsibility: Incorporating Equality" (2002) 25 Dal. L.J. 27; and Backhouse, "Gender and Race in the Construction of 'Legal Professionalism," supra note 10. On Canada's Aboriginal persons, see Larry Chartrand, "The Appropriateness of the Lawyer as Advocate in Contemporary Aboriginal Justice Initiarives" (1995) 33 Alta. L. Rev. 874. See Canadian Bar Association, "Guidelines for Lawyers Acting for Survivors of Aboriginal Residential Schools" (2000), online: <http://www.cba.org/cba/EPIIgram/february2002/Resolutions.pdf> [CBA, "Acting for Survivors of Aboriginal Residential Schools"]; Law Society of Yukon, Guidelines for Lauyers Acting for Survivors of Aboriginal Residential Schools (2000) [Yukon, "Acting for Survivors of Aboriginal Residential Schools"]; and Law Society of Upper Canada, Guidelines for Lawyers Acting in Cases involving Aboriginal Residential School Abuse, online: <http://www.lsuc.on.ca/media/guideline_aboriginal_res.pdf> [LSUC Guidelines, "Acting in Cases involving Aboriginal Residential School Abuse"]. See also Paul Jonathan Saguil, "Ethical Lawyering Across Canada's Legal Traditions: Can Indigenous Legal Principles Inform Legal Ethics?" (2006) [unpublished, draft paper on file with author].

19. Alice Woolley, "Integrity in Zealousness: Comparing the Standard Conceptions of the Canadian and American Lawyer" (1996) 9 Can. J.L. \& Jur. 61. 
mapping out an agenda for future scholarship. Part III introduces the idea of "waves" of legal scholarship. Essentially, I contend that we can think of different types of scholarship in terms of waves, the first of which consists of treatises and doctrinal analyses. In Part IV, I examine the second wave of scholarship of Canadian legal ethics, which is closely associated with Hutchinson's text and represents a deeper, more reflective and analytical, and at times critical, analysis of issues of legal ethics in Canada. In Part V, I turn to legal education and analyze significant developments that have taken place generally, and particularly with respect to legal ethics in the Canadian legal academy. Part VI articulates a proposal for a Canadian legal ethics research agenda, and the article ends with a brief conclusion in Part VII.

\section{A BRIEF HISTORY OF CANADIAN LEGAL ETHICS IN THE FIRST DECADE OF THE TWENTY-FIRST CENTURY}

Until recently, the Canadian legal academy was not particularly interested in legal ethics. Hutchinson attributes this to the lack of a defining Canadian cultural moment like Watergate "in which lawyers were placed under national scrutiny and obliged to reconsider the legitimacy of their professional practices and norms of conduct." ${ }^{20}$ While Hutchinson is correct that there has been no "lawyergate" in Canada to capture the public imagination, the last few years have seen numerous ethical scandals that, cumulatively, seemed capable of exerting some pressure on the legal profession. In this Part, I outline a brief history of Canadian legal ethics in the first decade of this century. For the most part, this history draws heavily on the public account of Canadian legal ethics, but also includes elements from the legal profession's account. The purpose of this section is to discuss examples of lawyers' poor ethical behaviour to which the public has been recently exposed and the legal profession's responses, or lack thereof in some cases, to these and other issues.

For Canadian legal ethics it has been an eventful and challenging decade. The twenty-first century began with the trial of Ken Murray, the lawyer originally retained to defend Canada's notorious murderer, Paul Bernardo. Murray was acquitted, barely, of obstruction of justice in connection with the infamous Bernardo/Homolka videotapes. ${ }^{21}$ The Law Society of Upper Canada

20. Hutchinson, Legal Ethics, supra note 3 at 5-6.

21. R. v. Murray (2000), 144 C.C.C. (3d) 289 (Ont. Sup. Ct. J.) (acquitting Murray of charges 
(LSUC) began a disciplinary investigation into Murray's conduct, but abandoned it in favour of enacting a rule of professional conduct on the issue of lawyers' duties respecting physical evidence of a crime. After releasing a draft rule, the LSUC shelved this project as well. The Murray case thus ended in three negatives: no conviction against Murray, no disciplinary action by the LSUC, and no action by the LSUC to address the issue. ${ }^{22}$

The next big ethical scandal involved law students, rather than lawyers. In 2001, thirty students at the University of Toronto Law School ("U of T" or "Toronto") were caught up in allegations of misrepresenting their grades to prospective summer employers, and twenty-four received sanctions ranging from reprimands to one-year suspensions. The $U$ of $T$ "fake grades scandal" also became an international cause célèbre in academic freedom circles because

of attempting to obstruct evidence by retaining physical evidence of a crime for seventeen months after his client Paul Bernardo had instructed him on how to locate videotapes which showed Bernardo committing crimes; Murray was acquitted on grounds that he lacked the mens rea to commit the crime).

22. For a critical reaction to the LSUC's decision to drop its disciplinary investigation against Murray, see "The Law Society failed the public," Editorial, The Globe and Mail (2 December 2000) F6. For the Law Society's reaction see Robert P. Armstrong \& Gavin MacKenzie, Letter to the Editor, "Law Society did not fail" The Globe and Mail (13 December 2000) A14. See also Kirk Makin, "A clean escape from the house of Bernardo" The Globe and Mail (30 November 2000) A1. After the acquittal of Ken Murray and the decision not to pursue disciplinary sanctions against him, the LSUC struck a special committee to propose a professional conduct rule for lawyers' duties respecting physical evidence of a crime. The Committee submitted a report to Convocation on 21 March 2002 with a proposed rule. See Special Committee on Lawyers' Duties with Respect to Property Relevant to a Crime or Offence, Report to Convocation (21 March 2002), online: <http://www.Isuc.on.ca/news/ $\mathrm{pdf} /$ convmay02_propertyrelecrime.pdf $>$. Convocation sought a legal opinion on the proposed rule. See "Law Society to obtain legal opinion on proposed conduct for lawyers" Canada Newswire (23 May 2002). The LSUC decided not to pursue the matter further, and as of December 2007, the Rules of Professional Conduct have not been amended to address this issue. Similarly, in its 2006 revision of its Code of Professional Conduct, the CBA did not address this issue. For a detailed analysis of the problem of the lawyer's duties respecting physical evidence of a crime, see Michel Proulx \& David Layton, Ethics and Canadian Criminal Law (Toronto: Irwin Law, 2001) at 481-530; Austin M. Cooper, "The Ken Murray Case: Defence Counsel's Dilemma" (2003) 47 Crim. L.Q. 141; and Kent Roach, "Smoking Guns: Beyond the Murray Case," Editorial Comment (2000) 43 Crim. L.Q. 409. For an example of a jurisdiction that does specifically address the lawyer's duty respecting physical evidence of a crime, see Alberta, Law Society of Alberta: Code of Professional Conduct, c. 10, r. 20, online: <http://www.lawsocietyalberta.com/files/Code.pd6s. 
of allegations against a $\mathrm{U}$ of $\mathrm{T}$ law professor. ${ }^{23}$ As might be expected, one of the students sought judicial review and succeeded in having the Dean's decision against her quashed on jurisdictional grounds. ${ }^{24}$ Three years later, another cheating scandal erupted in Toronto, this time at the LSUC's Bar Admission Course. However, while the U of T "fake grades scandal" dragged on for over a year, the Bar Admission Course cheating scandal ended abruptly after a few weeks. When the LSUC made an allegedly secret decision to abandon the investigation, ${ }^{25}$ the scandal continued to fester. ${ }^{26}$ In between the two Toronto student scandals, the President of the Law Society of British Columbia resigned in 2003, after a conviction for impaired driving, and was subsequently suspended from practice. ${ }^{27} \mathrm{He}$ would not be the last law society head during the decade forced to resign amidst ethical improprieties.

23. See Michael Valpy, "U of T suspends law students for year in fake-marks scandal" The Globe and Mail (2 May 2001) A1; Michael Valpy, "Nolo contendre" The Globe and Mail (4 May 2001) A11; Sean Fine, "U of T professor cleared in law-school grades affair" The Globe and Mail (19 June 2001) A5; Tracey Tyler, "Professor cleared in cheating probe. A 'vindication' for academic freedom, she says" Toronto Star (19 June 2001) A1; and James Cowan, "Atonement: when 24 students at U of T's Faculty of Law lied about their grades to land summer jobs, they tarnished the school's reputation and risked their own futures" Toronto Life 36:9 (June 2002) 57. For a catalogue of this whole affair, see the homepage of Toronto lawyer Selwyn Pieters, “The Inside Scoop! What's So Special About U of T Law," online: <http:/www.geocities.com/CapitolHill/2381/Lawschoolscase/cheatingscandal.html>.

24. See Shank v. Daniels (2002), 57 O.R. (3d) 559 (Sup. Ct. J.). See Graeme Smith, "Court quashes U of T student's suspension" The Globe and Mail (12 January 2002) A7.

25. See Tracey Tyler, "Cheating probe ends abruptly; Law students' e-mails probed: Governing body sworn to secrecy" Toronto Star (16 July 2004) Al (noting that thirteen articling students had been the subject of a Law Society investigation into allegations that they cheated on their bar admission course by sharing and copying work and that the investigation had been abruptly halted without any explanation).

26. See Tracey Tyler, "Law society urged to 'clear the air'; Cheating probe held in near secret; Elected governors want information" Toronto Star (17 July 2004) A4; Tracey Tyler, "Veil of secrecy called unacceptable; Bencher calls for Law Society head to resign; Controversy over handling of cheating probe" Toronto Star (4 August 2004) A4.

27. See Law Society of British Columbia, News Release, "Law Society of B.C. President resigns" (10 October 2003), online: <http://www.lawsociety.bc.ca/media/news/03-10-10_Berge.html>; "Lawyer who drank, drove suspended from practice" The Globe and Mail (22 December 2005) S3; and Re Howard Raymond Berge, Q.C. 2007 LSBC 07, online: <http://alt.lawsociery.bc.ca/ hearing_decisions/viewreport.cfm?hearing_id=235\&h=+berge\&h $>$. 
Lawyers' conduct in the courtroom and in the bedroom dominated ethical discussions at the beginning of this century. Midway through the decade, the CBA embarked on another revision to its Code of Conduct, which had not been overhauled since 1987. The revised CBA Code, based on amendments in 2004 and 2006, is notable mostly for what it did not address, rather than for any ethical boldness. The CBA ducked the Ken Murray problem, took a very modest approach to the issue of dealing with corporate fraud, and rejected a proposed amendment to restrict sexual relations between lawyers and clients, ${ }^{28}$ an issue that would resurface sooner rather than later. In 2007, the former Treasurer of the LSUC received a two-month suspension for conflict of interest arising out of a sexual relationship with a client who is now suing him and his law firm. ${ }^{29}$ Concerned also with lawyers' misbehaviour in the courtroom, the decade saw the rise of the civility and professionalism movement. Precipitated by the conduct of counsel in several cases, ${ }^{30}$ Ontario's Advocate's Society formed a Civility Committee, which produced a Code of Civility ${ }^{31}$ that the CBA included as an appendix in its revised Code. Similar concerns motivated the Nova Scotia Barristers' Society to establish a Task Force on Civility. Meanwhile, in British Columbia, solicitor Martin Wirick perpetrated the largest legal fraud in Canadian history, an estimated $\$ 50$ million, triggering the largest audit and investigation ever undertaken by the Law Society of British Columbia and sending shockwaves throughout the legal profession, as well as the real estate and business communities. ${ }^{33}$

28. See Michelle MacAfee, "Lawyers reject new rules restricting sex with clients" The Globe and Mail (16 August 2004) A1.

29. See Law Society of Upper Canada v. Hunter, 2007 ONLSHP 27. See Shannon Kari, "Former head of law society sued for $\$ 1.4 \mathrm{M}$ " National Post (5 January 2008) A6.

30. See R. v. Felderhof, [2002] C.C.S. No. 21535 (Sup. Ct. J.), affd (2003), 68 O.R. (3d) 481 (C.A.); Marchand v. Public General Hospital Society of Chatham (2000), 51 O.R. (3d) 97 (C.A.).

31. See The Advocates' Society, Principles of Civility for Advocates, online: <http://www.advocates.cal pdf/100_Civility.pd6. On civility see e.g. Michael Code, "Counsel's Duty of Civility: an Essential Component of Fair Trials and an Effective Justice System" (2007) 11 Can. Crim. L. Rev. 97; Alice Woolley, "Does Civility Matter?” (2008) 46 Osgoode Hall L.J. 175.

32. See Nova Scotia Barristers' Society, Task Force on Professional Civility 2002 Report, online: <http://www.nsbs.ns.ca/publications/civ.pdfs.

33. See David Baines, "Massive fraud puts law sociery on hook for up to $\$ 46$ million: Special fee on clients' real estate transactions will fund fraud claims" The Vancouver Sun (17 September 2002) A1; David Baines, "Time taken to investigate fraud case inordinate" The Vancouver Sun (25 
As class action lawsuits began proliferating across the country, the role of lawyers came under scrutiny, especially with regard to fees. Whether it was the $\$ 56$ million in fees for the settlement of the tainted blood scandal before a single victim was paid, or the $\$ 100$ million that Regina's Tony Merchant hoped to obtain as part of the record estimated $\$ 1.9$ billion settlement of residential schools abuse claims, public perception that lawyers put their own interests ahead of those of their clients ran high. ${ }^{34}$ Along these lines, concerns about lawyers taking advantage of vulnerable clients led the CBA, the Law Society of Yukon, and the LSUC to each establish guidelines for lawyers acting in Aboriginal residential school abuse cases. ${ }^{35}$

In the courts, the Supreme Court of Canada continued where it left off in Martin v. Gray (1990), ${ }^{36}$ issuing two decisions, Neil (2002) ${ }^{37}$ and Strother (2007), ${ }^{38}$ which helped keep conflict of interest at the top of the legal profession's ethical priority list. ${ }^{39}$ On the regulatory front, the Court held that

January 2006) D1. See also Law Society of British Columbia v. Wirick, 2002 LSBC 32. This case is chronicled in Philip Slayton, Lawyers Gone Bad: Money, Sex and Madness in Canada's Legal Profession (Toronto: Viking Canada, 2007) at 178-92 [Slayton, Lauyers Gone Bad].

34. On tainted blood, see Simon Tuck, "Victim fund in danger, Hepatitis C Society says" The Globe and Mail (3 June 2004) A9 (noting that legal fees and costs of administration had eaten up $\$ 91$ million or almost one quarter of the funds set aside for compensating Hepatitis $C$ victims). On Merchant, see Jonathon Gatehouse, "White man's windfall" Maclean's 119:35 (4 September 2006), online: <http://www.macleans.ca/canada/national/article.jsp?content= 20060911_133025_133025>; Timothy Taylor, "The Merchant of Menace" Report on Business Magazine (January 2008) at 24 (profiling the controversial Merchant who has been disciplined by the Law. Society of Saskatchewan on three occasions) [Timothy Taylor, "The Merchant of Menace"]. See also "School abuse deal includes $\$ 80 \mathrm{M}$ for lawyers" CBC News (8 May 2006), online: <http://www.cbc.ca/story/canada/national/2006/05/08/residential-legal-fees.html>.

35. See CBA Guidelines, Acting for Survivors of Aboriginal Residential Schools; Yukon Guidelines, "Acting for Survivors of Aboriginal Residential Schools"; and LSUC Guidelines, "Acting in Cases involving Aboriginal Residential School Abuse," supra note 18.

36. MacDonald Estate v. Martin, [1990] 3 S.C.R. 1235.

37. R. v. Neil, [2002] 2 S.C.R. 177.

38. Strother v. 3464920 Canada Inc., [2007] S.C.J. No. 24.

39. The sections on conflicts of interest are by far the longest of any subject in the codes of conduct. See e.g. CBA, Code of Professional Conduct, supra note 12, c. V (Impartiality and Conflict of Interest Between Clients) (20 pages). The second longest chapter is c. IX (The Lawyer as Advocate), which runs 14 pages. See also Law Society of Upper Canada, Rules of . Professional Conduct, rr. 2.04 (Avoidance of Conflicts of Interest) and 2.05 (Conflicts from Transfer Between Law Firms) (17 pages) [LSUC Rules]; Law Society of British Columbia, 
provincial law societies could not prohibit non-lawyers from appearing as counsel before the Immigration and Refugee Board, ${ }^{40}$ but that law societies do have the power to regulate Crown prosecutors. ${ }^{41}$ In a leading case, the Ontario Court of Appeal held that the Ontario Securities Commission (OSC) could regulate the conduct of lawyers appearing before it. ${ }^{42}$ The Supreme Court held that law societies do not have a general duty of care to persons who are defrauded by their lawyers, ${ }^{43}$ but also that law societies will not be immunized from liability by ignoring their statutory responsibilities to protect the public. ${ }^{44}$ Along these lines, the Court vindicated the Law Society of New Brunswick for meting out the ultimate sanction of disbarment to a lawyer who misled his clients for five years. ${ }^{45}$ The Court continued its strong interest in solicitor-client privilege that began in $1999,{ }^{46}$ deciding no fewer than eight cases since then, ${ }^{47}$

Professional Conduct Handbook, c. 6 (Conflicts of Interest Between Clients); and Nova Scotia Barristers' Society, Legal Ethics Handbook, c. 6 (Impartiality and Conflict of Interest Between Clients) and c. 6A (Conflicts Arising out of Transfer Between Law Firms). In March 2007, the CBA established a Task Force on Conflicts of Interest with a mandate (1) to propose practical guidelines for the profession (a) in applying the duty of loyalty, and (b) in implementing appropriate modifications or waivers of the duty; (2) to consider the appropriate scope and content of client engagement letters; and (3) to propose practical guidelines for the profession in the application of the duty of confidentiality, particularly in the areas of deemed knowledge and relevance of information. In October 2007, the CBA Task Force issued a Background Paper entitled Developing an Effective and Practical Conflicts of Interest Regime and also released a Consultation Paper, seeking feedback by the end of November 2007. The Task Force will then make recommendations to the CBA. See generally Canadian Bar Association Task Force on Conflicts of Interest, online: <http://www.cba.org/CBA/groups/conflicts/>.

40. See Law Society of British Columbia v. Mangat, [2001] 3 S.C.R. 113.

41. See Krieger v. Law Society of Alberta, [2002] 3 S.C.R. 372.

42. See Wilder v. Ontario Securities Commission (2001), 53 O.R. (3d) 519 (C.A.).

43. See Edwards v. Law Society of Upper Canada, [2001] 3 S.C.R. 562.

44. See Finney v. Barreau du Quebec, [2004] 2 S.C.R. 17. Philip Slayton writes about this case in Slayton, Lawyers Gone Bad, supra note 33 at 208-18. I was a member of Finney's legal team until the fall of 2003 when I joined the staff of Ontario's former Attorney General, the Hon. Michael Bryant.

45. See Law Society of New Brunswick v. Ryan, [2003] 1 S.C.R. 247 [Ryan]. I was co-counsel with Gavin MacKenzie for the intervenor Federation of Law Societies in this case.

46. See R. v. Campbell, [1999] 1 S.C.R. 565; Smith v. Jones, [1999] 1 S.C.R. 455.

47. See R. v. McClure, [2001] 1 S.C.R. 445; R. v. Brown, [2002] 2 S.C.R. 185; Lavallee, Rackel \&o Heintz v. Canada (Attorney General); White, Ottenheimer \& Baker v. Canada (Attorney 
and elevating that privilege to a constitutional right. ${ }^{48}$ The bar across Canada, led by the Federation of Law Societies, exerted tremendous energy and resources to successfully challenge regulations that, among other things, would have required lawyers to report "suspicious transactions" involving $\$ 10,000$ or more in cash. ${ }^{49}$

In the area of judicial ethics, the Court decided two cases regarding judicial discipline, one involving statements made by a judge in court, ${ }^{50}$ and the other concerning attempts to remove a judge because of a later-discovered criminal conviction. ${ }^{51}$ The Court dealt with two judicial disqualification cases, both of which arose under unique circumstances and both involving allegations of bias against members of the Court itself. First, in Wewaykum (2003), the losing

General); R. v. Fink, [2002] 3 S.C.R. 209; Maranda v. Richer, [2003] 3 S.C.R. 193;

Pritchard v. Ontario (Human Rights Commission), [2004] 1 S.C.R. 809; Goodis v. Ontario (Ministry of Correctional Services), [2006] 2 S.C.R. 32; Blank v. Canada (Minister of Justice), [2006] 2 S.C.R. 319; and Celanese Canada Inc. v. Murray Demolition Corp., [2006] 2 S.C.R. 189. See also Foster Wheeler Power Co. v. Société intermunicipale de gestion et d'élimination des déchets (SIGED) Inc., [2004] 1 S.C.R. 456 (on the related concept of professional secrecy under Quebec civil law). In one case, an issue relating to the privilege existed in the lower courts but the litigant no longer relied upon it by the time the case reached the Supreme Court. See London (City) v. RSJ Holdings, [2007] 2 S.C.R. 588.

48. See Mahmud Jamal \& Brian Morgan, "The Constiturionalization of Solicitor-Client Privilege" (2003) 20 Sup. Ct. L. Rev. (2d) 213.

49. See Law Society of British Columbia v. Canada (Attorney General) (2001), 207 D.L.R. (4th) 705, aff d [2002] 207 D.L.R. (4th) 736 (C.A.), leave to appeal granted 25 April 2002 and notice of discontinuance of appeal filed 25 May 2002, [2002] S.C.C.A. No. 52 (QL); Federation of Law Societies of Canada v. Canada (Attorney General), [2001] A.J. No. 1697 (QL) (Q.B.); Federation of Law Societies of Canada v. Canada (Attorney General (2002), 203 N.S.R. (2d) 53; Federation of Law Societies of Canada v. Canada (Attorney General) (2002), 57 O.R. (3d) 383 (Sup. Ct. J.); and Federation of Law Societies of Canada v. Canada (Attorney General) (2002), 218 Sask. R. 193. The Federation of Law Societies launched an assault on the federal government's money laundering reporting requirements. After several court decisions in the Federation's favour, the federal government settled these actions with the Federation. See Kirk Makin, "Ottawa gives up forcing lawyers to tell on clients" The Globe and Mail (25 March 2003) A13. In 2006, the government passed Bill C-25, which exempts lawyers from the reporting requirements of this regime, but would require lawyers to record all transactions of $\$ 3,000$ or more. The battle continues: see "Lawyers back on the hook in revised money laundering act" Law Times (16 July 2007), online: <http://www.lawtimesnews.com/ index.php?option $=$ com_content\&task=view\&id $=2503>$.

50. See Moreau-Bérubé v. New Brunswick (Judicial Council), [2002] I S.C.R. 249.

51. See Re Therrien, [2001] 2 S.C.R. 3. 
litigant before the Court was unsuccessful in its attempt to vacate the decision based on the alleged reasonable apprehension of bias arising from Justice Binnie's involvement in the case while holding the position of Associate Deputy Minister of Justice. ${ }^{52}$ Second, in Mugesera (2005), lawyer Guy Bertrand made accusations that a Jewish conspiracy had tainted the impartiality of the Court, which the Court found was an "unqualified and abusive attack on the integrity of the Judges of this Court." 53 Bertrand was later formally reprimanded by the Barreau du Quebec. ${ }^{54}$

Over the decade, access to justice was increasingly recognized as an important issue by the courts, the profession, and the media. The Court recognized a doctrine of advance costs but then significantly narrowed it. ${ }^{55} \mathrm{It}$ unanimously and unceremoniously rejected the constitutional claim for statefunded legal counsel in civil cases, ${ }^{56}$ and it forced a representative plaintiff to pay costs likely totaling over one million dollars in an unsuccessful class proceeding. ${ }^{57}$ The Court's treatment of access to justice issues was at odds with an increasingly strong cri de coeur being heard both within the profession ${ }^{58}$ and in the press. ${ }^{59}$ The Chief Justice of Canada and other justices and leaders of the

52. See Wewaykum Indian Band v. Canada, [2003] 2 S.C.R. 259 [Wewaykum (2003)]. See also Adam M. Dodek, "Constitutional Legitimacy and Responsibility: Confronting Allegations of Bias After Wewaykum Indian Band v. Canada" (2004) 25 Sup. Ct. L. Rev. (2d) 165 [Dodek, "Constitutional Legitimacy"].

53. See Mugesera v. Canada (Minister of Citizenship and Immigration), [2005] 2 S.C.R. 91 at 16 [Mugesera (2005)]. For earlier bias cases that have more general application see ArsenaultCameron v. Prince Edward Island, [1999] 3 S.C.R. 851 (dismissing motion to recuse Justice Bastarache because of his advocacy and scholarship in the area of language rights before being appointed to the bench); R. v. R.D.S., [1997] 3 S.C.R. 484 (allowing appeal from decision holding that trial judge's remarks created reasonable apprehension of bias).

54. See Guimont c. Bertrand, 2005 CanLII 57406 (QC C.D.B.Q.).

55. See British Columbia (Minister of Forests) v. Okanagan Indian Band, [2003] 3 S.C.R. 371; Little Sisters Book and Art Emporium v. Canada (Commissioner of Customs and Revenue), [2007] 1 S.C.R. 38.

56. See British Columbia (Attorney General) v. Christie, [2007] 1 S.C.R. 873.

57. See Kerr v. Danier Leather Inc., [2007] 286 D.L.R. (4th) 601; Jacquie McNish, "Plaintiff to foor bill as Danier wins" The Globe and Mail (13 Ocrober 2007) B7.

58. See e.g. The Right Honourable Beverley McLachlin, P.C., "The Challenges We Face" (Remarks presented at the Empire Club of Canada, 8 March 2007), online: <http://www.scc-csc.gc.ca/AboutCourt/judges/speeches/Challenges_e.asp>.

59. In Ontario, the Toronto Star began a series on access to justice in March 2007 with the 
bar frequently lament barriers to access to justice for Canadians, but have offered little in the way of solutions. One bright note has been the rise of institutionalized pro bono initiatives, through Pro Bono Law Ontario, Pro Bono Law of British Columbia, and now Pro Bono Law Alberta. Over the decade, the plight of self-represented litigants has increasingly caught the attention of Canada's judges, lawyers, policy-makers, and to some extent, the press. ${ }^{60}$

The years 2006 and 2007 might well be considered the legal profession's anni horribiles from the perspective of Canadian legal ethics. With British Columbia still reeling from the Wirick fraud, the Treasurer of the LSUC in Ontario resigned in January 2006 and was ultimately disciplined and suspended for two months in connection with a sexual relationship with a client. ${ }^{61}$ In August 2006, legal heavyweight Peter Shoniker pled guilty to money

attention-grabbing headline, "A 3-day trial likely to cost you $\$ 60,000$." See Tracey Tyler, "A 3-day trial likely to cost you $\$ 60,000$; But that won't cover an expert witness, or opponent's legal costs if you lose" Toronto Star (3 March 2007) A25 [Tyler, "A 3-day trial likely to cost you $\$ 60,000 "]$. For other articles in this series see Tracey Tyler, "The dark side of justice" Toronto Star (3 March 2007) A1; Tracey Tyler, "Legal aid rules shut out thousands; Many earning under $\$ 16,000$ face uphill battle trying to represent themselves in complex cases" Toronto Star (3 March 2007) A24; Tracey Tyler, "Ever-expanding trials; not our fault Defence lawyers" Toronto Star (5 March 2007) A8; Tracey Tyler, "A 'ruinous' system for losers; Canadian courts that award financially punitive lawyers' costs create a 'huge barrier' to legal access, say judges and lawyers" Toronto Star (30 March 2007) A3; and Tracey Tyler, "Small claims hit the big time" Toronto Star (28 July 2007) ID1. See also John Intini, "No Justice for the Middle Class" Maclean's 120:35/36 (10 September 2007) 68; Canadian Judicial Council, "Access to Justice: Meeting the Challenge (2006-2007 Annual Report)" (Ottawa: Canadian Judicial Council, 2007).

60. See e.g. ibid.

61. See Law Society of Upper Canada, "Law Society of Upper Canada Announcement" (23 January 2006), online: <http://www.lsuc.on.ca/media/jan2306hunter.pdfs. Hunter had tendered his resignation in December 2005 but Convocation chose to treat it as a request for a leave of absence, and bencher Clayton Ruby became Interim Treasurer until Gavin MacKenzie was elected in a special election. The election was held in February 2006 after Hunter permanently resigned. See Law Society of Upper Canada, “Law Society of Upper Canada Announcement" (7 December 2005), online: <http://www.lsuc.on.ca/latestnews/b/archives/index.cfm?c=1029\&i=8432>; Law Society of Upper Canada, "Law Society of Upper Canada Announcement" (9 December 2005), online: <http://www.lsuc.on.ca/latestnews/b/archives/index.cfm?c=1029\&i=8450>; Tracey Tyler, "Clayton Ruby to lead law society; Treasurer resigned for 'family reasons'; Ruby automatically moves to top post" Toronto Star (8 December 2005) B.04; and Law Society of Upper Canada, "Gavin MacKenzie elected Treasurer of the Law Society of Upper Canada" (23 February 2006), 
laundering and was sentenced to fifteen months of incarceration. ${ }^{62}$ In the spring of 2007, lawyers from Torys LLP were frequently in the news in relation to advice that they gave Conrad Black and other members of Hollinger Inc. regarding non-compete agreements at the center of the Black trial in Chicago. In a deal struck between Torys and the prosecution, the Torys lawyers-not subject to the jurisdiction of the American courts-agreed to testify by recorded videotape in Toronto, with resulting negative press coverage of the lawyers and the law firm. ${ }^{63}$ Not to be missed, of course, was the fact that two of the defendants in the Black trial were lawyers: Mark Kipnis and Peter Atkinson (a member of the Ontario bar and a former Torys partner). Rarely mentioned was the fact that Conrad Black is a law graduate (Laval), although not a member of the bar.

In July, lawyers were featured on the cover of Maclean's under the headline "Lawyers Are Rats" with titles above various lawyers reading, "I Pad My Bills," "I'm Dishonest," "I sleep with my clients," and "I take bribes" among other things. ${ }^{64}$ The cover accompanied an interview with Philip Slayton, ethics

online: <http://www.Isuc.on.ca/media/feb2306_new_treasurer.pdfs. On the Law Society's discipline of Mr. Hunter see supra note 29.

62. R. v. Shoniker, [2006] O.J. No. 5368 (Sup. Ct. J.) (QL); Peter Brieger, "Cash sting lawyer: 'I'm guilty'" National Post (19 August 2006) A12, online: <http://www.nationalpost.com/ news/toronto/story.html? id =50d2db24-cdbb-4739-bl fa-a32a7c24c84e>. Of Shoniker, Canadian Lawyer said: "At the pinnacle of his career, [he] met the Pope and could count generals, police chiefs, judges, and politicians among his coterie of friends and acquaintances. At his nadir, he was a shattered man sitting in a Toronto courtroom ... ." See Bruce Livesey, "Fall from grace: The Rise and Fall of Peter Shoniker" Canadian Lawyer (September 2007) 34.

63. See Jacquie McNish \& Paul Waldie, "Advisers won't look 'this jury in the eye" The Globe and Mail (22 March 2007) Al; Paul Waldie, "Focus turns to former Hollinger lawyers" The Globe and Mail (9 April 2007) A11; Paul Waldie, "Lawyer in CanWest deal comes under the gun" The Globe and Mail (12 April 2007) A2; Margaret Wente, "The brilliant career of Mr. Sukonick" The Globe and Mail (12 April 2007) A17; Rick Westhead, "Defence spotlights lawyer's message" Toronto Star (13 April 2007) A12; Paul Waldie, "Non-compete payments increased before Can West deal, lawyer testifies" The Globe and Mail (13 April 2007) A14; Rick Westhead, "Black saga hasn't hurt law firm; Torys LLP lawyer suffers verbal mauling but, observers say, prestige is still intact" Toronto Star (14 April 2007) A10; Paul Waldie, "Lawyer 'shocked' by Torys' take on his advice" The Globe and Mail (17 April 2007) A18; Paul Waldie, "Former Torys' lawyer squirms over questions about her income" The Globe and Mail (20 April 2007) A2; Paul Waldie, "Key witness lied, lawyer says" The Globe and Mail (22 June 2007) A14; and Jacquie McNish, "Penalties for referees who didn't blow the whistle" The Globe and Mail (14 July 2007) A8.

64. Maclean's 120:30 (6 August 2007) cover. 
columnist for Canadian Lawyer and former law professor, law dean, Bay Street lawyer, and author of Lawyers Gone Bad: Money, Sex and Madness in Canada's Legal Profession. ${ }^{65}$ The sensationalism of Maclean's succeeded in provoking a rash of responses from the organized bar as well as from its individual members. ${ }^{66}$ It was likely responsible for temporarily catapulting Slayton's anecdotal collection of lawyer malfeasance onto the bestseller list where it quietly retreated after having wrought havoc on the legal profession for two months.

The year ended with a collective sigh of relief from the legal profession with the Competition Bureau of Canada's report on self-regulated professions, including law. ${ }^{67}$ The legal profession had been anxiously awaiting this report, looking over its shoulder at the changes precipitated by similar reports in the United Kingdom and the European Union. ${ }^{68}$ On 11 December 2007, the Commissioner released her report amidst minimal fanfare and negligible public interest. ${ }^{69}$ While the follow-up remains uncertain, law societies will be

65. Philip Slayton, Lawyers Gone Bad, supra note 33.

66. See Letters to the Editor, Maclean's 120:31/32 (13 August 2007) 4-6 (including letters from CBA President J. Parker MacCarthy, numerous lawyers, and members of the public); and the magazine's unusually long defence of the article in its column "From the Editors": "Not just a lone voice in the wilderness," Editorial, Maclean's 120:31/32 (13 August 2007) 2. See also Law Society of Upper Canada, News Release, "Maclean's article a disservice to Canadians" (30 July 2007), online: <http://www.lsuc.on.ca/media/jul3007_ macleans_article.pdf;; Michael Milani, "Who lawyers the lawyers? We do, and it works" The Globe and Mail (9 August 2007) A17; Natalie Fraser, "Lawyers get mad about Lauyers Gone Bad" The Lawyers Weekly (10 August 2007) 1. For an excellent perspective see Alan Young, "We're Not Rats... But Snooty Lawyers are bullying their way out of favour" NOW Magazine (6 September 2007), online: Now <http://www.nowtoronto.com/issues/2007-0906/news_story6_p.html/s.

67. See Competition Bureau of Canada, Report, Self-Regulated Professions-Balancing Competition and Regulation (11 December 2007) [Competition Bureau, Self-Regulated Professions). (The professions studied included accountants, lawyers, optometrists, pharmacists, and real estate agents).

68. See UK, Secretary of State for Constitutional Affairs, Review of the Regulatory Framework For Legal Services in England and Wales by Sir David Clementi (London: Ministry of Justice, 2004); and Legal Services Act 2007 (UK), 2007, c. 29.

69. See e.g. Virginia Galt, "Shakeup urged for the professions" The Globe and Mail (12 December 2007) B5; Madhavi Acharya \& Tom Yew, "Watchdog scrutinizes professions; Protect consumers first, self-regulators are told" The Toronto Star (12 December 2007) B1; and William Watson, "Professional protection" National Post (14 December 2007), online: <http://www.nationalpost.com/rss/Story.html?id=166988>. A search conducted in January 
able to make small changes in response to the Competition Bureau's report without upsetting the apple cart.

Thus ended the Canadian legal profession's two-year anni horribiles, with a whimper not a bang. Somewhat surprisingly, these events appear not to have had much impact on the level of public trust towards lawyers in Canada, which actually went up in 2006 and again in 2007 after a decrease for several years in a row. In 2007, 54 per cent of Canadians said that they trust lawyers, the same level as in 2002. This is a much lower level of trust than that received by perennial favourites-firefighters (97 per cent) and nurses (94 per cent)-but far ahead of politicians (15 per cent) and used car salespersons (12.per cent). ${ }^{70}$ While the decade was full of ethical lows and challenges for the Canadian legal profession, Hutchinson's point, first made in 1999, that there has not been a single defining cultural moment for lawyering in Canada, is still the case. Despite the absence of a "lawyergate" that succeeded in capturing the public imagination and spurring an agenda for reform; many of the events described above did have an impact within the profession and the legal academy. Importantly, these events helped stimulate some of the initiatives described in Parts III and IV below, and certainly provided both motivation and opportunities for the scholarship described in the following parts. ${ }^{71}$

2008 on FP Infomart - a database containing the leading newspapers in Canada-revealed only six stories on the report, including wire stories. There was no formal reaction by the Federation of Law Societies. See Federation of Law Societies, "What's New," online: <http://www.flsc.ca/en/whatsnew/whatsnew.asp>. A review of the websites of all of the law societies in Canada reveals no press releases or statements in response to the report. See e.g. Law Society of Upper Canada, News Releases, online: <http://www.Isuc.on.ca/latest-news/ b/news-releases/index.cfm?expandYear=2007 >; Law Society of British Columbia, MediaNews Releases, online: <http://www.lawsociety.bc.ca/media/news/intro.html>. For a report on the reaction of the legal profession see Michael Rappaport, "Competition bureau's study draws tepid reaction from legal community" The Lawyers Weekly (11 January 2008), online: <http://www.lawyersweekly.ca/index.php?section=article\&articleid=599>. In this article, Queen's law professor Paul Paton refers to the study as "not as bold as it could be."

70. See Leger Marketing, Report, "Profession Barometer" (15 May 2007), online: $<$ http://www.legermarketing.com/documents/spclm/070522ENG.pdfs. The level of trust in lawyers was highest in the Atlantic provinces (57\%) and lowest in British Columbia (46\%). Consistent with the national trend, public trust in lawyers actually increased in Ontario between 2006 (48\%) and 2007 (51\%), despite or irrespective of the various public scandals there.

71. In a paper that he presented at the Law Society of Alberta's 100th Anniversary, Richard Devlin offered ten reasons that raise concern that the regulation of the legal system might 


\section{THE FIRST WAVE OF CANADIAN LEGAL ETHICS SCHOLARSHIP}

Canadian legal ethics scholarship can be thought of as a series of waves, ${ }^{72}$ with each wave representing a particular approach to legal scholarship. Rather than supplanting each other, they co-exist and indeed draw upon one another. The first wave consists of doctrinal analysis, and is heavily focused on the codes of ethics and on law societies' regulations. This wave has existed since at least Orkin's 1957 book, ${ }^{73}$ but only operated in fits and spurts since that time. It was given a tremendous boost with the 1993 publication of MacKenzie's treatise, Lawyers and Ethics, ${ }^{74}$ which continues to be a leading source in the field. MacKenzie, along with Justice Mary Newbury of the British Columbia Court of Appeal and Toronto lawyer/writer Derek Lundy, ${ }^{75}$ were the founding editors of a new loose-leaf by Butterworths in the late 1990s, modeled on the English

not be working as well as it should in a democratic society. There is significant overlap between Devlin's list and my account in this part. Devlin's list contains: (1) The Ken Murray case; (2) Disclosure of Imminent Financial Harm; (3) Protection of the Public from Incompetent Lawyers, i.e., the Finney case, supra note 44; (4) Sexual Relations with a Client / George Hunter; (5) Discipline in the Protection of Victims of Residential Schools; (6) Billing and Fees in the Residential Schools Cases; (7) Mandatory Continuing Legal Education; (8) Fees and Concerns over Access to Justice; (9) Self-Represented Litigants in Court; and (10) Pro Bono. See Richard Devlin, "The End(s) of Self-Regulation" (Paper presented at the Law Society of Alberta's 100th Year Anniversary Conference, "Canadian Lawyers in the 21 st Century," Edmonton, Alberta, 27 October 2007), Alta. L. Rev. [forthcoming in 2008] [Devlin, "Self-Regulation"].

72. In my earlier article, Dodek, "A Subject in Search of Scholarship," supra note 1 at 119, 122, I wrote about first and second generations of scholarship on Canadian legal ethics. I think it makes more sense to conceive of different approaches as waves, rather than as generations which succeed each other. In this I owe a debt of gratitude to the excellent article which analyzes different conceptions of access to justice in terms of successive waves. See Roderick A. Macdonald, "Access to Justice in Canada Today: Scope, Scale, Ambitions" in Julia Bass, W.A. Bogart \& Frederick H. Zemans, eds., Access to Justice for a New Century: The Way Forward (Toronto: Law Society of Upper Canada, 2005) 19 at 20-23, [Bass, Bogart \& Zemans, Access to Justice for a New Century].

73. Orkin, Legal Ethics, supra note 4.

74. See MacKenzie, supra note 5.

75. Derek Lundy spearheaded the Barristers \& Solicitors in Practice (BSIP) project. He is the best-selling author of The Bloody Red Hand: A Journey through Truth, Myth and Terror in Northern Ireland (Toronto: Knopf Canada, 2006); The Way of a Ship: A Square-Rigger Voyage in the Last Days of Sail (Toronto: Knopf Canada, 2002); Godforsaken Sea: Racing the World's Most Dangerous Waters (Toronto: Knopf Canada, 1998); and Scott Turow: Meeting the Enemy (Toronto: ECW Press, 1995). 
text, Cordery on Solicitors. ${ }^{76}$ On this basis, Barristers \& Solicitors in Practice ${ }^{77}$ was conceived as a treatise on the law of lawyering, focusing on the structure of the legal profession and issues such as accepting and carrying out instructions, professional relationships, advertising, professional conduct, professional liability, conflicts of interest, financial regulation, remuneration, and professional indemnity. Under the editorship of the late Justice Ken Lysyk of the British Columbia Court of Appeal and Professor Lorne Sossin, the mandate of the text was expanded and chapters on legal aid, mediation, and injunctions were added. Under new editors, ${ }^{78}$ the text is currently being updated and new chapters are planned to reflect current issues in the legal profession, including pro bono, paralegals, and unrepresented litigants. The text will be relaunched later in 2008 with a broader focus on all the actors in the legal system: lawyers, judges, and paralegals, among others.

Meanwhile, in 2006, LexisNexis commenced publication of the first edition of Halsbury's Laws of Canada ${ }^{79}$ modeled on Halsbury's Laws of England and the various other Halsbury's series in the common law world. ${ }^{80}$ At its completion, Halsbury's Laws of Canada will comprise some fifty-seven volumes. One of the first volumes, published at the end of 2007, is on the topic of Legal Profession. ${ }^{81}$ Other loose-leaf treatises produced over the last decade have reflected some of the predominant issues of the era: conflicts of interest ${ }^{82}$ and privilege. ${ }^{83}$

76. See Cordery on Solicitors, 9th rev. ed., (London: Butterworths Law, 1995) (loose-leaf). As one of the original contributors to BSIP (with Jerome D. Ziskrout for the chapter on Professional Conduct), I recall being sent the corresponding chapter of Cordery on Solicitors and being instructed to follow that format. See also the comments of Derek Lundy in the original Preface to Adam M. Dodek \& Jeffrey G. Hoskins, Barristers \& Solicitors in Practice (Markham: LexisNexis Canada, 2007) at 1 (Preface).

77. Dodek \& Hoskins, ibid.

78. Ibid.

79. Halsbury's Laws of Canada, (Markham: LexisNexis, 2006).

80. Lord Hailsham of St. Marylebone, ed., Halsbury's Laws of England, 4th ed. (London: Butterworths, 1973); see e.g. Halsbury's Laws of Australia (Sydney: Butterworths, 1991).

81. Halsbury's Laws of Canada, 1st ed., Legal Profession (Markham: LexisNexis Canada, 2007).

82. See M. Deborah MacNair, Conflicts of Interest: Principles of the Legal Profession (Aurora: Canada Law Book, 2005).

83. See Robert W. Hubbard, Susan Magotiaux \& Suzanne M. Duncan, The Law of Privilege in Canada (Aurora: Canada Law Book, 2006). For another comprehensive treatise see Beverley G. Smith, Professional Conduct for Lauyers and Judges, 3d ed. (Fredericton: Maritime Law Book, 2007). 
The most ambitious treatise published over the last decade is the Ethics and Canadian Criminal Law, ${ }^{84}$ by the late Justice Michel Proulx of the Quebec Court of Appeal and criminal lawyer David Layton, now of Vancouver and formerly of Toronto and Halifax. This 2001 treatise is widely recognized as a tour de force in its field, and is frequently cited by the Supreme Court and other courts. ${ }^{85}$ Ethics and Canadian Criminal Law bridges the first and second waves of Canadian legal ethics scholarship. Not only does it analyze particular ethical issues facing criminal lawyers, but it also directly tackles some of the most vexing matters in the field and prescribes its own solutions. For example, it provides the best treatment of the "Ken Murray problem"- a lawyer's duties respecting physical evidence of a crime, an issue that, as we have seen, the law societies and the CBA have failed to address adequately. ${ }^{86}$ For this reason the book is praised, appreciated, and referenced by jurists, lawyers, and scholars across the country. An updated and revised edition is planned and will be eagerly received.

\section{THE SECOND WAVE AND THE RISE OF THE NEW LEGAL ETHICS SCHOLARS}

The second wave of scholarship of Canadian legal ethics moves beyond the descriptive into the analytical and prescriptive. It comprises scholarly writings that may be analytical, critical, prescriptive, or some combination thereof. The intellectual progenitor of the second wave is Harry Arthurs, who has tilled this scholarly soil mostly alone. ${ }^{87}$ Other scholars contributed noteworthy works,

84. Proulx \& Layton, supra note 22.

85. Ethics and Canadian Criminal Law received the 2003 Walter Owen Book Prize from the Foundation for Legal Research in recognition of "outstanding new contributions to Canadian legal literature that enhance the quality of legal research in this country." See The Walter Owen Book Prize, online: <http://www.irwinlaw.com/newsdetail.aspx?newsid=51 >.

86. See Proulx \& Layton, supra note 22 at 481-530.

87. For Harry Arthurs' work on the legal profession during these lean years of legal ethics scholarship, see "The Study of the Legal Profession in the Law School" (1970) 8 Osgoode Hall L.J. 183; "Discipline in the Legal Profession in Ontario" (1970) 7 Osgoode Hall L.J. 235; "Toronto Legal Profession: An Exploratory Survey" (1971) 21 U.T.L.J. 498;

"Authority, Accountability and Democracy in the Government of the Ontario Legal Profession" (1971) 49 Can. Bar Rev. 1; "Counsel, Clients and Community" (1973) 11 Osgoode Hall L.J. 437; "The Future of Legal Services" (1973) 51 Can. Bar Rev. 15; "Progress and Professionalism: The Canadian Legal Profession in Transition" (1973) Law \& 
which should be considered part of this genre; ${ }^{88}$ however, the body of scholarship did not start to coalesce into a notable and coherent subject matter until recently.

Soc'y 1; "Barristers and Barricades: Prospects for the Lawyer as a Reformer" (1976) 15 U.W.O. L. Rev. 59; "Paradoxes of Canadian Legal Education" (1977) 3 Dal. L.J. 639; "Le droit vit-il à l'heure de sa société: allocution" (1978) 13 Thémis 243; "To Know Ourselves: Exploring the Secret Life of Canadian Legal Scholarship" (1985) 23 Osgoode Hall L.J. 403; "Law, Sociery and the Law Sociery" (1993) 27 L. Soc'y Gaz. 85; "The Dead Parrot: Does Professional Self-Regulation Exhibit Vital Signs?" (1995) 33 Alta. L. Rev. 800 [Arthurs, "The Dead Parrot"]; "A Lot of Knowledge is a Dangerous Thing: Will the Legal Profession Survive the Knowledge Explosion?" (1995) 18 Dal. L.J. 295; "Law, Legal Institutions, and the Legal Profession in the New Economy" (1996) 34 Osgoode Hall L.J. 1; "Lawyering in Canada in the $21^{\text {st }}$ Century" (1996) 15 Windsor Y.B. Access Just. 202; "Globalization of the Mind: Canadian Elites and the Restructuring of Legal Fields" (1997) 12:2 C.J.L.S. 219; "Why Canadian Law Schools Do Not Teach Legal Ethics," supra note 5; with Richard Weisman \& Frederick H. Zemans, "Canadian Lawyers: A Peculiar Professionalism" in Richard L. Abel \& Philip S.C. Lewis, eds., Lauyers in Society: The Common Law World (Berkeley: University of California Press, 1988) 123; and with David A.A. Stager, Lawyers in Canada (Toronto: University of Toronto Press, 1990) [Stager \& Arthurs, Lawyers in Canada].

88. There were a number of symposia or special editions of journals in the $1990 \mathrm{~s}$ which produced thoughtful articles in the area. In August 1995, the Alberta Law Review published a special edition on "The Legal Profession and Ethics" (1995) 33 Alta. L. Rev. 719-943. Articles include Justice J.C. Major, "Lawyers' Obligation to Provide Legal Services" at 719; W. Wesley Pue, "In Pursuit of Better Myth: Lawyers' Histories and Histories of Lawyers" at 730 [Pue, "In Pursuit of Better Myth"]; Allan C. Hutchinson, "Calgary and Everything After: A Postmodern Re-vision of Lawyering" at 768 [Hutchinson, "Calgary and Everything After"]; Carole Curtis, "Alternative Visions of the Legal Profession in Society: A Perspective on Ontario" at 787; H.W. Arthurs, "The Dead Parrot: Does Professional Self-Regulation Exhibit Vital Signs?" at 800; Esmeralda M.A Thornhill, "Ethics in the Legal Profession: The Issue of Access" at 810; Dianne Pothier, "On Not "Getring It" at 817; The Hon. Wendy G. Baker, "Structure of the Workplace or, Should We Continue to Knock the Corners Off the Square Pegs or Can We Change The Shape of the Holes?" at 821; Alan D. Hunter, "A View as to the Profile of a Lawyer in Private Practice" at 831; Jonnette Watson Hamilton, "Metaphors of Lawyers' Professionalism" at 833; Gavin MacKenzie, "The Valentine's Card in the Operating Room: Codes of Ethics and the Failing Ideals of the Legal Profession" at 859; Larry Chartrand, "The Appropriateness of the Lawyer as Advocate in Contemporary Aboriginal Justice Initiatives" at 874; René Laperriére, "L'éthique Et La Responsabilité Professionnelle Des Juristes En Matière De Compétence" at 882; A. Wayne MacKay, "Some Thoughts on a More Humanist and Equitable Legal Education" at 920; and Richard F. Devlin, "Normative, and Somewhere to Go? Reflections on Professional Responsibility" at 924 [Devlin, "Reflections"]. 
With the rise of a new group of legal ethics scholars in Canada over the past decade, the second wave reached critical mass. This group is not new relative to any older, earlier group (which could not be said to exist as an identifiable group). Rather, it is new in the sense of being novel to the Canadian legal academy. These "New Legal Ethics Scholars" consist both of scholars who are actively engaged in research in Canadian legal ethics as a significant component of their research agenda, as well as scholars who teach in the growing area and who may publish ethics-related articles from time to time. $^{89}$ To a large degree, this group is represented in the composition of a

In 1996, the Canadian Journal of Law and Jurisprudence also published a symposium edition on legal ethics. See (1996) 9 Can. J.L. \& Jur. 3 et seq. (wherein David Luban speaks prematurely of "A New Canadian legal ethics" in his introduction). Articles in this collection include David Luban, "Introduction: A New Canadian legal ethics?" at 3; Hon. James M. Spence, "Called to the Bar" at 5; Susan P. Koniak, "Law and Ethics in a World of Rights and Unsuitable Wrongs" at 11; Gavin MacKenzie, "Breaking the Dichotomy Habit: The Adversary System and the Ethics of Professionalism" at 33; Jerome E. Bickenbach, "The Redemption of the Moral Mandate of the Profession of Law" at 51; Alice Woolley, "Integrity in Zealousness: Comparing the Standard Conceptions of the Canadian and American Lawyer" at 61 [Woolley, "Zealousness"]; Richard Bronaugh, "Thoughts on Money, Winning, and Happiness in the Pracrice of Law" at 101; Donald E. Buckingham, "Rules and Roles: Casting Off Legal Education's Moral Blinders for an Approach that Encourages Moral Development" at 111; Barry Hoffmaster, "Hanging Out a Shingle: The Public and Private Services of Professionals" at 127; and Peter Mercer, Margaret Ann Wilkinson \& Terra Strong, "The Practice of Ethical Precepts: Dissecting Decision-Making by Lawyers" at 141. Of the Canadians in this group (Luban and Koniak are American legal academics), a few-including Alice Woolley of the University of Calgary and Mary Ann Wilkinson and Peter Mercer of the University of Western Ontario- continued with subsequent scholarly work in legal ethics. See Margaret Ann Wilkinson, Christa Walker \& Peter Mercer, "Testing Theory and Debunking Stereotypes: Lawyers' Views on the Practice of Law" (2005) 18 Can. J.L. \& Jur. 165; Margaret Ann Wilkinson, Christa Walker \& Perer Mercer, "Do Codes of Ethics Acrually Shape Legal Practice?" (2000) 45 McGill L.J. 645; and Margaret Ann Wilkinson, Peter Mercer \& Terra Strong, "Mentor, Mercenary or Melding: An Empirical Inquiry into the Role of the Lawyer" (1996) 28 Loy. U. Chicago L.J. 373.

89. In this vein see David M. Tanovich, "Law's Ambition and the Reconstruction of Role Morality in Canada" (2005) 28 Dal. L.J. 267 (Tanovich teaches The Legal Profession at Windsor); Devlin, Downie \& Lane, supra note 11; Jocelyn Downie, "A Case for Compulsory Legal Ethics Education in Canadian Law Schools" (1997) 20 Dal. L.J. 224 (Downie reaches The Legal Profession and Professional Responsibility at Dalhousie); Anne McGillivray, "He Would Have Made a Wonderful Solicitor: Law, Modernity and Professionalism in Bram Stoker's Dracula" in W. Wesley Pue \& David Sugarman, eds., Lawyers and Vampires: Cultural Histories of Legal Professions (Oxford: Hart Publishing, 2003) 
Canadian legal ethics and professional responsibility curricular nerwork, the Legal Ethics Curriculum Network, established in 2006, which met that year in Halifax ${ }^{90}$ and in 2007 in Edmonton. However, other practitioner-scholars who are actively engaged in scholarship in the area, such as David Layton ${ }^{91}$ and Gavin MacKenzie, should also be considered part of this group of New Legal Ethics Scholars in Canada.

The New Legal Ethics Scholars includes established scholars who have turned their attention to the discipline with some regularity, such as Richard Devlin (Dalhousie University (Dalhousie)) $)^{92}$ and Allan Hutchinson (Osgoode). ${ }^{93}$ Additionally, newer scholars, such as Michael Code (Toronto), ${ }^{94}$

225 [Pue \& Sugarman, Lauyers and Vampires]; and Anne McGillivray, "'A moral vacuity in her which is difficult if not impossible to explain': Law, psychiatry and the remaking of Karla Homolka" (1998) 5 Int'l J. Legal Prof. 255 [McGillivary, "A moral vacuity"] (McGillivray teaches The Legal Profession and Professional Responsibility at Manitoba).

90. Devlin, Downie \& Lane, ibid. at 767.

91. For publications by David Layton see e.g. Proulx \& Layton, supra note 22; "Defence Counsel's Ethical Duties and Frivolous Charter Applications" The Verdict 110 (October 2006) 25; "The Public Safety Exception: Confusing Confidentiality, Privilege and Ethics" (2001) 6 Can. Crim. L. Rev. 217; and "The Pre-Trial Removal of Counsel for Conflict of Interest: Appealability and Remedies on Appeal" (1999) 4 Can. Crim. L. Rev. 25.

92. For publications by Richard Devlin see e.g. "Self-Regulation," supra note 71; Devlin, Downie \& Lane, supra note 11; "Conflicts of Interest: Where Are We Since R. v. Neil?" The Society Record 30:6 (2005) 113; "Of Legends and Pro Bono" Lawyers' Weekly 25:32 (23 December 2005); with Jocelyn Downie, "Self Regulation in the Shire" Society Record 22:1 (2004) 18; "Jurisprudence for Judges: Or, Why Legal Theory Matters for Social Context Education" (2001) 27 Queen's L.J. 161, translated and republished as "la théorie générale du droit pour les juges" (2002) 4 R.C.L.F. 197; with Natasha Kim \& A. Wayne MacKay, "Reducing the Democratic Deficit: Representation, Diversity and the Canadian Judiciary, or Towards a 'Triple P' Judiciary" (2000) 38 Alta. L. Rev. 734; "Judging and Diversity: Justice or Just Us?/Les Décisions Judicaires et la Diversité: La Justice des Justiciables ou de justiciers?" (1996) 20:3 Prov. Judges J. 4; Book Reviews of Judicial Conduct and Accountability by David Marshall and A Place Apart: Judicial Independence and Accountability in Canada by Martin Friedland, (1996) 75 Can. Bar Rev. 398; "We Can't Go On Together with Suspicious Minds: Judicial Bias and Racialized Perspective" (1995) 18 Dal. L.J. 408; and "Reflections," supra note 88 at 924.

93. For publications by Allan Hutchison see e.g. Legal Ethics, supra note 3; "Who are 'Clients'? (And Why it Matters)" (2006) 84 Can. Bar Rev. 411; "Taking it Personally: Legal Ethics and Client Selection" (1998) 1 Legal Ethics 168; "Legal Ethics for a Fragmented Society: Between Professional and Personal" (1998) 5 Int'l J. Legal Prof. 175; and Hutchinson, "Calgary and Everything After," supra note 88. 
Randal Graham (University of Western Ontario (Western)), ${ }^{95}$ Paul Paton (Queen's University (Queen's)), ${ }^{96}$ and Alice Woolley (University of Calgary (Calgary)), ${ }^{97}$ devote a significant portion of their research to issues of legal ethics, which is a truly "new" development in Canadian legal ethics. ${ }^{98}$ These

94. For publications by Michael Code see e.g. "Crown Counsel's Responsibilities when advising the Police at the Pre-Charge Stage" (1998) 40 Crim. L.Q. 326; with Kent Roach, "The Role of the Independent Lawyer and Security Certificates" (2006) 52 Crim. L.Q. 85; "Counsel's Duty of Civility: an Essential Component of Fair Trials and an Effective Justice System" (2007) 11 Can. Crim. L. Rev. 97; and with Kent Roach, "The Independence of the Bar and the public interest imperative: lawyers as garekeepers, whistleblowers, or instruments of state enforcement" in In the Public Interest: The Report and Research Papers of the Law Society of Upper Canada's Task Force on the Rule of Law and the Independence of the Bar (Toronto: Irwin Law, 2007) 151.

95. For publications by Randal N.M. Graham see e.g. "In Defence of Ethinomics" (2005) 8 Legal Ethics 160; “Morality v. Markets: An Economic Account of Legal Ethics” (2005) 8 Legal Ethics 87; Legal Ethics: Theories, Cases and Professional Regulation (Toronto: Emond Montgomery Publications, 2004); and "Moral Contexts" (2001) 50 U.N.B.L.J. 77.

96. For publications by Paul D. Paton see e.g. "Accountants, Privilege and the Problem of Working Papers" (2005) 28 Dal. L.J. 353; "Corporate Counsel as Corporate Conscience: Ethics and Integrity in the Post-Enron Era" (2006) 84 Can. Bar Rev. 533; and with Deborah L. Rhode, "Lawyers, Ethics and Enron" (2002) 8 Stan. J.L. Bus. \& Fin. 9. Professor Paton is leaving Canada to take up a position at McGeorge University of the Pacific in Sacramento, California in the summer of 2008.

97. For publications by Alice Woolley see e.g. "Imperfect Duty: Lawyers' Obligation to Foster Access to Justice" (Paper presented at the Law Society of Alberta's 100th Year Anniversary Conference, "Canadian Lawyers in the 21 st Century," Edmonton, Alberta, 27 October 2007), (2008) 46 Alta. L. Rev. [forthcoming] [Woolley, "Imperfect Duty"]; "Tending the Bar: The Good Character Requirement for Law Society Admission" (2008) 31 Dal. L.J. [forthcoming] [Woolley, "Tending the Bar"]; with Sara L. Bagg, "Ethics Teaching in Law School" (2007) 1 Can. Legal Educ. Ann. Rev. 85; "Evaluating Value: A Historical Case Study of the Capacity of Alternative Billing. Methods to Reform Unethical Hourly Billing" (2005) 12 Int'l J. Legal Prof. 339; "Can the Dismal Science Save the 'Dog of the Curriculum'?" (2005) 8 Legal Ethics 148 (Review Essay of Randal N. Graham's Legal Ethics, supra note 95); "Time for Change: Unethical Hourly Billing in the Canadian Profession and What Should be Done About It" (2004) 83 Can. Bar Rev. 859; and "Zealousness," supra note 88 at 61 .

98. I would place myself in this category of devoting a significant portion of my research to issues of legal ethics. See Adam M. Dodek \& Jeffrey G. Hoskins, eds., Barristers and Solicitors in Practice (Toronto: LexisNexis, 2007); "Constitutional Legitimacy," supra note 52; "Forsaking the Public Interest: Law Society of New Brunswick v. Ryan" (2002) 25 Advocates' Q. 230; "Doing our Duty: The Case for a Duty of Disclosure to Prevent Death or Serious Harm" (2001) 50 U.N.B.L.J. 215; "The Public Safety Exception to Solicitor-Client 
scholars were strongly influenced by comparative legal ethics, whether through doing graduate work in the United States with some of the leading figures of American legal ethics, ${ }^{99}$ or through research leave in the United Kingdom. ${ }^{100}$ It should be noted that the late Rose Voyvodic of University of Windsor's Faculty of Law (Windsor) greatly enriched the scholarship of Canadian legal ethics before she passed away in April 2007.101 The group also encompasses Wesley Pue (University of British Columbia (UBC)), who has been producing penetrating accounts of legal education, the profession, and its culture and history for the last two decades. ${ }^{102}$ In addition, some excellent sociological and

Privilege: Smith v. Jones" (2001) 34 U.B.C. L. Rev. 293; "A Subject in Search of Scholarship," supra note 1; and "Comparative Confidentiality: Lessons From Canada" (1995) 20 J. Legal Prof. 51 [Dodek, "Comparative Confidentiality"].

99. Paul Paton studied and collaborated with Deborah Rhode at Stanford Law School. Alice Woolley did her LL.M. at Yale and studied with David Luban. Trevor Farrow worked with Andrew Kaufman at Harvard Law School while obtaining his LL.M. and visiting on a fellowship. In my case, I obtained my J.D. at Harvard Law School and took the mandatory course in The Legal Profession with Professor Daniel Coquillette, who inspired my interest in the subject and also encouraged me to publish my first law review article. See Dodek, "Comparative Confidentiality," ibid.

100. Allan Hutchinson was the Inns of Court Fellow in the Legal Profession at Lincoln's Inn and the Institute for Advanced Legal Studies in London, England. See Hutchinson, Legal Ethics, supra note 3 at xviii.

101. See e.g. Rose Voyvodic, "Lawyers Meet Social Context: Understanding Cultural Competence" (2006) 84 Can. Bar Rev. 563; “'Change is Pain': Ethical Legal Discourse and Cultural Competence" (2005) 8 Legal Ethics 55.

102. See especially Pue \& Sugarman, Lawyers and Vampires, supra note 89; "Globalization and Legal Education: Views from the Outside-In" (2001) 8 Int'l J. Legal Prof. 87; with Annie Rochette, "Back to Basics? University Legal Education and 21st Century Professionalism" (2001) 20 Windsor Y.B. Access Just. 167; with Ruth Buchanan \& Marilyn MacCrimmon, "Legal Knowledge for Our Times: Introduction to a Symposium on Education and Legal Knowledge" (2001) 20 Windsor Y.B. Access Just, xiii; with Dawna Tong "The Best and the Brightest? Canadian Law School Admissions" (1999) 37 Osgoode Hall L.J. 843; "British Masculinities, Canadian Lawyers: Canadian legal education, 1900-1930" (1999) 16 Law in Context 80; "Lawyering for a Fragmented World: Professionalism after God" (1998) 5 Int'l J. Legal Prof. 125; "Common Law Legal Education in Canada's Age of Light, Soap and Water"(1995) 23 Man. L.J. 654; "In Pursuit of Better Myth," supra note 88; "A Profession in Defense of Capital?" (1992) 7:2 C.J.L.S. 267; "Becoming 'Ethical': Lawyers' Professional Ethics in Early Twentieth Century Canada" (1991) 20 Man. L.J. 227; "Moral Panic at the English Bar: Paternal vs. Commercial Ideologies of Legal Practice in the 1860s" (1990) 15 Law \& Soc. Inquiry 49; "Rethinking 'Professionalism': Taking The Professions in Early 
historical work has been done on the sociology of the profession and on women in the profession by Constance Backhouse (Ottawa), ${ }^{103}$ Joan Brockman (Simon Fraser University), ${ }^{104}$ Fiona Kay (Queen's), ${ }^{105}$ Jean McKenzie Leiper (Western), ${ }^{106}$ and Mary Jane Mossman (Osgoode). ${ }^{107}$

Modern England Seriously" (1989) 4 C.J.L.S. 175; and "Guild Training vs. Professional Education: The Committee on Legal Education and the Law Department of Queen's College, Birmingham in the 1850s" (1989) 33 Am. J. Legal Hist. 241. For a list of Professor Pue's publications see online: University of British Columbia, Faculty of Law <http://faculty.law.ubc.ca/Pue/index-pub.html>.

103. For publications by Constance Backhouse see e.g. "What is Access to Justice?" in Bass, Bogart \& Zemans, Access to Justice for a New Century, supra note 72; "The Chilly Climate for Women Judges: Reflections on the Ewanchuk Decision" (2003) 15 C.J.W.L. 167; "The Changing Landscape of Canadian Legal Education" (2001) 20 Windsor Y.B. Access Just. 25; "Bias in Canadian Law: A Lopsided Precipice" (1998) 10 C.J.W.L. 170; and Petticoats and Prejudice: Women and Law in Nineteenth-Century Canada (Toronto: Women's Press for the Osgoode Society, 1991). For a complete list of Professor Backhouse's publications, see online: <http://www.constancebackhouse.ca/publications/other-publications.html>.

104. For publications by Joan Brockman see e.g. "An Update on Self-Regulation in the Legal Profession (1989-2000): Funnel In and Funnel Out" (2004) 19:1 C.J.L.S. 55; "Aspirations and Appointments to the Judiciary" (2003) 15 C.J.W.L. 138; with Caroline Murdoch, "Who's On First? Disciplinary Proceedings by Self-Regulating Professions and other Agencies for 'Criminal' Behaviour" (2001) 64 Sask. L. Rev. 29; "A Wild Feminist at Her Raving Best: Reflections on Studying Gender Bias in the Legal Profession" (2000) 28:1 Resources for Feminist Research 61; with Fiona M. Kay, "Barriers to Gender Equality in the Canadian Legal Establishment" (2000) 8 Fem. Legal Stud. 169; "AA Cold-Blooded Effort to Bolster Up the Legal Profession': The Battle Between Lawyers and Notaries in British Columbia, 1871-1930" (1999) 32 Social History 209; and Gender in the Legal Profession: Fitting or Breaking the Mould (Vancouver: UBC Press, 2001).

105. For publications by Fiona M. Kay see e.g. "The Social Significance of the First Women Lawyers" (2007) 45 Osgoode Hall L.J. 397; with Jean E. Wallace, "The Professionalism of Practicing Law: A Comparison Across Two Work Contexts" (Paper presented at the AGM of the American Sociological Association, Montreal, Quebec, Canada, 11 August 2006) [unpublished]; with John Hagan, "Even Lawyers Get the Blues: Gender, Depression and Job Satisfaction in Legal Practice" (2007) 41 Law \& Soc'y Rev. 51; "Professionalism and Exclusionary Practices: Shifting the Terrain of Privilege and Professional Monopoly" (2004) 11 Int'l J. Legal Prof. 3; with John Hagan, "Building Trust: Social Capital, Distributive Justice and Loyalty to the Firm" (2003) 28 Law \& Soc. Inquiry 483; "Crossroads to Innovation and Diversity: The Careers of Women Lawyers in Quebec" (2002) 47 McGill L.J. 699; with Joan Brockman, "Barriers to Gender Equality in the Canadian Legal Establishment" (2000) 8 Fem. Legal Stud. 169; with John Hagan, "Cultivating Clients in the Competition for Partnership: Gender and Organizational Restructuring of Law Firms in the 1990s" (1999) 33 Law \& Soc'y Rev. 517; and with John Hagan, Gender in Practice: $A$ 
The individual members of the New Legal Ethics Scholars are focusing on different subject areas, such as criminal (Layton, Code), corporate (Paton), clinical (Voyvodic), and civil (Farrow). They encompass and employ different schools of legal thought, including economic analysis of the law (Graham), law and society (Pue), feminist legal analysis (Voydovic, Mossman, and others), and sociological analysis (Kay). Some are looking at micro-issues in the profession, while others are examining macro-issues, such as the good'character requirement or civility. ${ }^{108}$ Together, they have begun to build the foundarions of an identifiable scholarly discipline of legal ethics in Canada.

One of the projects that the Legal Ethics Curriculum Network is working on is a national legal ethics casebook ${ }^{109}$ to be used in the growing number of legal ethics courses offered in Canadian law schools, described in Part IV. Another member of this group, Western's Randal Graham, produced a casebook in 2004 that has been adopted by several law schools. Graham has produced a coherent theory of legal ethics based on rational choice theory which he calls "ethinomics." Graham's provocative and path-breaking theory has rightly attracted much attention and debate internationally, though not yet in Canada. ${ }^{110}$

Study of Lawyers' Lives (New York: Oxford University Press, 1995). For a complete list of Professor Kay's publications, see online: Queen's University, Department of Sociology <http://queensu.ca/sociology/files/Recent\%20Publications.pdfs.

106. See Jean McKenzie Leiper, Bar Codes: Women in the Legal Profession (Vancouver: UBC Press, 2006).

107. For publications by Mary Jane Mossman see e.g. The First Women Lawyers: A Comparative Study of Gender, Law and the Legal Professions (Oxford: Hart Publishing, 2006); "Legal Education as a Strategy for Change in the Legal Profession" in E. Sheehy \& S. McIntyre, eds., Calling for Change (Ottawa: University of Ottawa Press, 2006) 179; "Defining Moments for Women as Lawyers: Reflections on the Impact of Numerical Gender Equality" (2005) 17 C.J.W.L. 15; and "Gender Bias and the Legal Profession: Challenges and Choices" in J. Brockman \& D. Chunn, eds., Investigating Gender Bias: Law, Courts, and the Legal Profession (Toronto: Thompson Educational Publishing, 1993) 147. For a complete list of Professor Mossman's publications, see online: Osgoode Hall Law School <http://osgoode.yorku.ca/osgmedia.nsf/research/mossman_mary_jane>.

108. See Woolley, "Tending the Bar," supra note 97.

109 Alice Woolley et al., Legal Ethics and Professional Responsibility (Toronto: LexisNexis Canada) [forthcoming in 2008].

110. Graham's theory was the subject of an entire edition of the English journal, Legal Ethics. See W. Bradley Wendel, "Review Symposium: Introduction: Economic Rationality vs. Ethical 
In the civil justice area, the greatest strides in terms of ethics have been made in the alternative dispute resolution (ADR) field. ${ }^{11}$ Ethical issues concern significant sections of three new books on ADR. The University of Saskatchewan's Marjorie Benson conducted an important study involving lawyers in Alberta and Saskatchewan, first reported in the Canadian Bar Review in 2006, ${ }^{112}$ and now completed in a 2008 monograph. ${ }^{113}$ Although Benson's study found that ethical issues pervade the practice of negotiation, her study was unable to demarcate a clear line between "ethical" and "best practice" issues. This is an important point which can be expanded across the practice of law. In many cases, discipline issues arise because of the failure or refusal of a lawyer to address a practice issue which then leads the lawyer to make clear ethical missteps. ${ }^{114}$ In the second book, The Theory and Practice of Representative Negotiation, ${ }^{115}$ Osgoode's Colleen Hanycz, Trevor Farrow, and Frederick

Reasonableness: The Relevance of Law and Economics for Legal Ethics" (2005) 8 Legal Ethics 107; Kim Economides \& Julian Webb, "Ethinomics and the Determinants of Legal Professionalism" (2005) 8 Legal Ethics 1; David McGowan, "Some Realism about Parochialism: The Economic Analysis of Legal Ethics" (2005) 8 Legal Ethics 117; Duncan Webb, "The Boundaries of Economic Analysis-Is Ethinomics Possible?" (2005) 8 Legal Ethics 138; and Alice Woolley, "Can the Dismal Science Save the 'Dog of the Curriculum'?" (2005) 8 Legal Ethics 148.

111. For selected articles before the rise of the new scholarship of legal ethics see e.g. Connie Reeve, "The Quandary of Setting Standards for Mediators: Where Are We Headed?" (1998) 23 Queen's L.J. 441; Owen V. Gray, "Protecting the Confidentiality of Communications in Mediation" (1998) 36 Osgoode Hall L.J. 667; and Michael Coyle, "Defending the Weak and Fighting Unfairness: Can Mediators Respond to the Challenge?" (1998) 36 Osgoode Hall L.J. 625.

112. See Marjorie L. Benson, "A Negotiating Ethics Study" (2006) 84 Can. Bar Rev. 593.

113. Marjorie L. Benson, The Skills and Ethics of Negotiation: Wisdom and Reflections of Western Canadian Civil Practitioners (Saskatoon: College of Law, University of Saskatchewan, 2007).

114. Ryan, supra note 45, is a clear example of this. See especially paras. 3-10. The lawyer took a small cash retainer from two clients to initiate a wrongful dismissal case. Ryan never filed suit, and after missing the limitations period he "spun an elaborate web of deceit" for five and a half years, including inventing tales of imaginary motions, taking his clients to the site of a non-existent discovery, and forging a judgment of the New Brunswick Court of Appeal. Finally, Ryan admitted to his clients that the "whole thing was a lie" and was disbarred by the Law Society of New Brunswick.

115. See Colleen M. Hanycz, Trevor C.W. Farrow \& Frederick H. Zemans, The Theory and Practice of Representative Negotiation (Toronto: Emond Montgomery, 2008). See also Trevor C.W. Farrow, "The Negotiator-as-Professional: Understanding the Competing Interests of a Representative Negotiator" (2007) 7 Pepp. Disp. Resol. L.J. 373. 
Zemans devote a specific chapter to ethics, and ethical issues run through the entire book, with chapters devoted to each of gender, culture, and power. The final book, reviewed in this issue, ${ }^{116}$ is the broadest of the three. In The New Lawyer, ${ }^{117}$ Julie Macfarlane of the University of Windsor's Faculty of Law examines how structural changes within the profession and the legal system, namely a movement away from protracted litigation and towards conflict resolution, are changing the dominant legal norms and creating new ethical complexities across different areas of the law. While Macfarlane has been writing about ethical issues in ADR for some years, ${ }^{118}$ this book expands the analysis into a much broader field.

\section{REINVIGORATING LEGAL EDUCATION}

The growth of legal ethics within the academy can be attributed, in part, to larger changes within Canadian law schools. This past decade has been a period of reform and renewal at many of the country's law faculties. With many of the baby boomers retiring, law schools like Osgoode and UBC will see approximately 40 per cent of their faculty replaced by 2010 . Stable or increased budgets have allowed some law schools to increase their faculty complements. Calgary is expanding its law school entering class by a quarter and will have to add new faculty accordingly. Many law schools have completed (UBC, Calgary, Osgoode, Ottawa, Western, Windsor, McGill) or are undergoing (Toronto, University of New Brunswick (UNB)) curricular reforms. In almost every case, legal ethics has been the beneficiary of such reforms. There are a number of proposals for new law faculties in Ontario. ${ }^{119}$ There has not been a new law

116. See Andrew Pirie, Book Review of The New Lawyer: How Settlement is Transforming the Practice of Law by Julie Macfarlane, (2006) 46 Osgoode Hall L.J. 203.

117. Julie Macfarlane, The New Lawyer: How Settlement is Transforming the Practice of Law (Vancouver: UBC Press, 2008).

118. See Julie Macfarlane, "Mediating Ethically: The Limits of Codes of Conduct and the Potential of a Reflective Practice Model" (2002) 40 Osgoode Hall L.J. 49; Julie Macfarlane, "Culture Change: A Tale of Two Cities and Mandatory Court-Connected Mediation" (2002) J. Disp. Resol. 242.

119. See Helen Burnett, "Wilfrid Laurier throws hat in for law school; two universities in the hunt" The Law Times (24 September 2007) 4; Louise Brown \& Tracey Tyler, "4 universities vie for law school; Lakehead, Laurier, Waterloo among institutions seeking Law Sociery's approval to start programs" The Toronto Star (24 April 2008) A2; and "Another Law 
school in Ontario in almost four decades (Windsor, 1969) or in Canada for three decades (Moncton, 1978). The sudden interest in opening new law faculties for the first time in decades has coincided with the establishment of a task force by the LSUC to examine licensing and accreditation issues, including the review of criteria for approving law degrees for the first time in thirty-five years. ${ }^{120}$ The Federation of Law Societies is undertaking a similar review of the basis for accrediting foreign law degrees as equivalent to a Canadian law degree. Both reviews will be forced to consider the question of what legal education should consist of in the twenty-first century. An interim report by the LSUC task force already identifies professional responsibility as a component of legal education. ${ }^{121}$ It is highly likely that such reviews will include recognition that legal ethics and professional responsibility should be a component of Canadian legal education in the twenty-first century.

For years, legal ethics was a victim of academic inertia. ${ }^{122}$ The openness to reform and the ability to implement proposed changes has assisted the rise of legal ethics within Canadian law schools. Whereas in 1999 it was reported that only four of the country's sixteen common law schools required their students to take a course in legal ethics, ${ }^{123}$ now no less than nine have some

School?" Toronto Star (27 April 2008) A16 (noting Law Society of Upper Canada's approval in principle of new law school at Lakehead University in Thunder Bay).

120. See Law Society of Upper Canada, Ontario Lawyers' Gazette (Spring 2007) 34, online: <http://www.lsuc.on.ca/media/olg_spring07_task_force.pdf>. In addition to the passage of time, one of the precipitating factors in launching this review was the Government of Ontario's passage of the Fair Access to Regulated Professions Act, 2006 S.O. 2006, c. 31. The task force provided an interim report to Convocation in September 2007. See Law Society of Upper Canada, Licensing and Accreditation Task Force, Report to Convocation (20 September 2007), online: <http://www.lsuc.on.ca/media/convsept07_licensing accreditation.pdf $>$ [LSUC, Task Force]. Reference to the Federation's Task Force is found at para. 13. See also Law Society of Upper Canada, Consultation Report (January 2008), online: <http://www.lsuc.on.ca/media/licensing.pdf>.

121. See LSUC, Task Force, ibid. at para. 8.

122. See Devlin, Downie, \& Lane, supra note 11 at 762-65 (describing institutional resistance, faculty resistance, and student resistance). On leadership in reforming the law school curriculum see Stephen G.A. Pitel, "Charting New Courses: Leadership in Curriculum Reform" (Paper Presented at the Eighth Colloquium on the Legal Profession at the University of Western Ontario, London, Ontario, 25 May 2007), online: <http://www.lsuc.on.ca/media/eighth_colloquium_charting_new_courses.pdf .

123. Hutchinson, Legal Ethics and Professional Responsibility, 1st ed., supra note 3 at 4 . 
mandatory legal ethics course or component in their curriculum (UBC, University of Alberta, Calgary, Manitoba, Osgoode, Toronto, Western, Dalhousie and UNB), while two others (Ottawa and Windsor) integrate ethics into aspects of the first year curriculum. I predict that there will be more course offerings in the coming years. In addition, in the coming decades we will see the impact of paralegal regulation in Ontario and perhaps in other provinces as well. Might we see a law faculty offering degrees in paralegal studies as well as law? Might some twenty-first century Caesar Wright ${ }^{124}$ propose that first-year law students and first-year paralegal students sit side by side in some classes? These cultural, conceptual, pedagogical, and ethical challenges remain in the distance.

In the teaching of legal ethics, the lack of consistency is particularly noteworthy. As Sossin has explained, ${ }^{125}$ there are at least five ways to teach legal ethics: (1) the "integrated" or "pervasive" method, where there is no dedicated ethics course, but rather ethical issues are integrated throughout the curriculum's offerings; (2) the clinical method, whereby all students have some exposure to the real-world issues of working with clients through the clinical setting; (3) the combined method, where legal ethics and professionalism is integrated into another course, such as legal research and writing or civil litigation; (4) the dedicated course method, either mandatory or elective; and (5) not at all, on the assumption that the bar admission course will contain an ethics component. Even within this list, there is a multiplicity of approaches to the "dedicated course" method. Some schools (Calgary, Alberta, and UNB) offer the traditional course in upper years; orhers have a dedicated first-year week (Toronto and UBC) or course (Western). Osgoode has embarked on an ambitious non-traditional program of teaching legal ethics through a threeweek intensive course for first-year students, delivered in the first week of law school in September and the first two weeks in January. What is different today, compared to even a decade ago, is that there is now some precedent for

124. Cecil ("Caesar") Wright founded the modern University of Toronto Faculty of Law. See C. Ian Kyer \& Jerome E. Bickenbach, The Fiercest Debate: Cecil A. Wright, the Benchers and Legal Education in Ontario 1923-1957 (Toronto: The Osgoode Society, 1987); Martin L. Friedland, The University of Toronto: A History (Toronto: University of Toronto Press, 2002).

125. Lorne Sossin, “Can ethics be taught?" The Lawyers Weekly 26:45 (6 April 2007) 5. See also Woolley \& Bagg, supra note 97; and Devlin, Downie, \& Lane, supra note 11. See also the relevant articles by Pue, supra note 102. 
teaching legal ethics in Canada, and a diversity of approaches for doing so. There is a basis for discussion of a variety of questions: Should the course be mandatory or voluntary? First year or upper year? Integrated, clinical, combined, or dedicated approach? The New Legal Ethics Scholars have written a number of articles, and there now exists enough interest and experience to justify a conference on the subject this year. ${ }^{126}$

The expansion of legal ethics in the academy has been supported by and has led to the establishment of several centres and symposia. In Ontario, former Chief Justice Roy McMurtry established an Advisory Committee on Professionalism in September 2000. ${ }^{127}$ This initiative-composed of and targeting members of the judiciary, the Law Society, the legal academy, and the bar-has provided a strong injection of ideas and participants to the academic consideration of legal ethics in Ontario; its influence has been felt in other provinces as well. The Advisory Committee's first priority was to establish a definition of professionalism which eventually resulted in a ten-page document on the "Elements of Professionalism." 128 The most enduring and vitalizing contribution of the Advisory Committee has been the establishment of an annual or semi-annual Colloquium on the Legal Profession, which rotates among Ontario's six law schools. The First Colloquium took place at Western in October 2003, and the Tenth Colloquium at Ottawa in March 2008. The Eleventh Colloquium is scheduled for Windsor in October 2008. Each colloquium has been organized around a theme, such as Legal Ethics in Action (Osgoode, October 2007); Professionalism: Ideals, Challenges, Myths and Realities (Ottawa, March 2008); and Professionalism and Serving Communities (Windsor, October 2008). These colloquia have brought

126. See articles cited ibid. The new Centre for Professionalism, Ethics and Public Service (PEPS) is to hold its inaugural symposium in April 2008 on the subject of how to teach legal ethics. See The Centre for Professionalism, Ethics and Public Service (PEPS), online: University of Toronto <http://www.law.utoronto.ca/faculty_content.asp?itemPath=1/9/12/0/0\& contentld=1602\&cType=webpages $>$.

127. See Law Society of Upper Canada, Advisory Committee on Professionalism, online: <http://www.lsuc.on.ca/news/a/hottopics/committee-on-professionalism/>.

128. See Chief Justice of Ontario Advisory Committee on Professionalism, Working Group on the Definition of Professionalism, "Elements of Professionalism" (October 2001, rev. December 2001, June 2002), online: <http:/www.lsuc.on.ca/media/ definingprofessoct2001 revjune2002.pdfs. 
together leading members of the bar, the bench, and academia, and have featured papers generally of very high quality, all of which are available on the LSUC website. ${ }^{29}$

The Advisory Committee also established a Task Force on advancement of the ideal of professionalism, which held a conference in 2004 on teaching professionalism. Following the conference, the Task Force created two subgroups for teaching professionalism in law schools and in the first five years of practice. The sub-group on law school teaching led by Stephen Pitel (Western) created a database in CD-ROM format containing national legal ethics syllabi, course problems, and articles used in legal ethics courses. ${ }^{130}$ They are now exploring moving the database to a web-based format.

Two centres for legal ethics are planned. The Legal Ethics Curriculum Network is establishing a Virtual Centre for Legal Ethics \& Professional Responsibility to connect those working in the field from across the country. The Virtual Centre intends to work on the creation and dissemination of teaching materials and to hold meetings and conferences on the subject. In January 2008, the University of Toronto launched the Centre for Professionalism, Ethics, and Public Service (PEPS) under the directorship of Lorne Sossin. ${ }^{131}$ The goal of PEPS is to broaden and deepen our understanding of professionalism, ethics, and public service, and the relationship between them. It is designed to bring together academic programming, career and professional development, and public service and student leadership. It will feature a working paper series, ethics and public interest fellowships, a judge-inresidence program, a law, ethics, and film initiative, and a student leadership forum. In April 2008, it hosted a symposium on ethics and legal education entitled: "Can Ethics be Taught?"

129. See Law Society of Upper Canada, "Papers from Past Colloquia," online: <http://www.lsuc. on.ca/latest-news/a/hottopics/committee-on-professionalism/papers-from-past-colloquia/>.

130. See Stephen G.A. Pitel, Peter Buza \& Michael Beeforth, "Legal Ethics and Professionalism Teaching Materials Database” CD-ROM: (Faculty of Law, University of Western Ontario, Chief Justice of Ontario's Advisory Committee on Professionalism, September 2007).

131. See University of Toronto, Centre for Professionalism, Ethics and Public Service (PEPS), online: $<$ http: $/ /$ www.law.utoronto.ca/visitors_content.asp?itemPath $=5 / 12 / 0 / 0 / 0 \&$ contentId $=1602>$. 


\section{A RESEARCH AGENDA FOR CANADIAN LEGAL ETHICS IN THE TWENTY-FIRST CENTURY}

In Part I of this article, I identified both the collective and the individual components of Canadian legal ethics, as well as the challenge of attempting to situate any analysis within a distinctly Canadian legal culture and legal system. There, I noted the existence of gaps between different accounts of Canadian legal ethics: the popular account, the legal profession's account, and the scholarly account. In this Part, I take stock of where Canadian legal ethics is currently situated and present some issues to pursue as the scholarship moves forward, in part addressing some of the gaps between those accounts as well as the issue of the existence of such gaps.

First, there is a continued need to expand and revise the work of the first wave of Canadian legal ethics, the treatises, and other works that provide doctrinal description and analysis. First wave materials provide the most frequently consulted sources for practitioners, students, and scholars interested in Canadian legal ethics, and offer important source materials for those researching and writing in the area. Fruitful areas for ethical inquiry and analysis would include family law, immigration law, corporate law, public law, and civil litigation, to name a few. Here, there can be no better model than Proulx \& Layton's Ethics and Canadian Criminal Law. ${ }^{132}$ Second, there is a pressing need to expand the critical work begun by the New Legal Ethics Scholars into previously unexplored terrain. If the existing work in legal ethics in Canada could be seen as a map, we would have a much distorted picture of the ethical world; it would be distorted both in the sense of the ethical issues that lawyers face, as well as the ethical challenges for the profession and the legal system.

This gap between various accounts of ethical issues is a starting point for macro-ethical inquiry. In Part II, above, I described the key ethical moments and issues for the Canadian legal profession. If we were to compare these with where law societies and bar associations have focused their energies over the last decade, we would find a significant "ethical gap." We would find that a few issues have taken up a tremendous proportion of their "ethical energy" during this period to the diminishment or exclusion of many other issues. Thus, law societies and bar associations have been focused on issues like conflicts of

132. Proulx \& Layton, supra note 22. 
interest, independence of the bar, and money laundering. Codes of conduct are similarly distorted. ${ }^{133}$ As Harry Arthurs and others have forcefully demonstrated, they contain many provisions that should be considered purely aspirational and have virtually no regulatory impact: competency, lawyers' duty to the administration of justice, and civility, among others. On the other hand, they are largely silent when it comes to some of the most important and pressing ethical issues of the new century: lawyers' duties respecting the physical evidence of crime, the challenges of corporate counsel in the wake of numerous corporate scandals, and lawyers' responsibilities regarding access to justice.

I devoted an entire part to the issue of change in legal education because it is closely tied to legal ethics in a number of ways. The obvious ones are curriculum offerings and scholarship, but legal education is itself a subject for ethical inquiry. The plethora of proposals and possibilities for new law schools (part-time, distance learning, foreign law programs catering to Canadian students, et cetera) raise additional ethical issues. Restricting access to legal education is difficult to justify on access to justice grounds, but whether there is an ethical imperative for more lawyers is a more difficult question which implicates larger public policy questions, including the legitimacy of spending public funds on the training of more lawyers at the expense of other career options. To some degree, these are issues that provincial ministries of education, as opposed to law societies, will have to deal with. However, they will require law societies to consider their nebulous but critically important "public interest" mandate.

Continuing with macro-ethical issues, the leading ethical challenge for the profession and for the legal system is access to justice. Until recently, the access to justice "crisis" had succeeded in flying below the public radar. It was one of the worst kept secrets among lawyers that "the system" had, for the most part, priced all but the very poor (in the case of legal-aid-qualifying criminal defendants) and the relatively wealthy (individuals and companies) out of the market for justice in many provinces. A simple but poignant headline in the Toronto Star tells the tale: "A 3-day trial likely to cost you $\$ 60,000$."134 While the crisis in access to justice has received increased mainstream media attention,

133. See Hutchinson, Legal Ethics, supra note 3 at 13-17.

134. See Tyler, “A 3-day trial likely to cost you $\$ 60,000$," supra note 59 and additional articles from the Toronto Star cited therein. 
it has yet to register on the public radar as a political issue. The problem is that middle class Canadians, with whom political power arguably resides, do not experience the law the way that they do health care. The legal issues that most Canadians are likely to deal with involve residential real estate transactions and drawing up. wills, both areas which continue to be hotly competitive and eminently affordable. It is only in the rare instances when ordinary Canadians go to court or are named in a lawsuit that they get a rude awakening. Ethical inquiries into the access to justice crisis would involve attempting to determine responsibility for the rising costs of both civil and criminal litigation. All players in the legal system-courts, lawyers, government, litigants-share some responsibility for these problems and, therefore, they must share some responsibility to work towards a solution. The extent of this responsibility and the types of potential solutions are subjects of fruitful ethical inquiries. ${ }^{135}$ Ethical inquiries into access to justice issues would also scrutinize whether the profession is asking the right questions. The profession and the courts have tended to see access to justice in many of the wrong places; over the last decade, the Supreme Court of Canada, with support from the bar, has constitutionalized solicitor-client privilege, justifying it, in part, in terms of access to justice. ${ }^{136}$ Extending the access to justice rhetoric to such subjects is, at the least, misplaced and, at worst, misleading and counterproductive.

135. On this issue see Woolley, "Imperfect Duty," supra note 97; Richard Devlin, "Breach of Contract? The New Economy, Access to Justice and the Ethical Responsibilities of the Legal Profession” (2002) 25 Dal. L.J. 335; and Zino I. Macaluso, “That's Okay, This One's On Me: A Discussion of the Responsibilities and Duties. Owed by the Profession to do Pro Bono Publico Work" (1992) 26 U.B.C. L. Rev. 65. I consider the specific issue of self-represented litigants under the larger one of access to justice. On self-regulated litigants see e.g. Philip Slayton, "The self-representation problem" Canadian Lawyer (November/December 2007) 30; Coulter A. Osborne, Q.C., Civil Justice Reform Project: Summary of Findings and Recommendations (November 2007) at 3, 44-52, online: <http://www.attorneygeneral.jus.gov.on.ca/english/about/pubs/cjrp/CJRP-Report_EN.pdf>; Canadian Forum on Civil Justice, Alberta Self-Represented Litigants Mapping Project Final Report (January 2007), online: <http://cfcj-fcjc.org/docs/2007/mapping-en.pdf;; and Canadian Judicial Council, Statement of Principles on Self-represented Litigants and Accused Persons (September 2006), online: <http://www.cjc-ccm.gc.ca/cmslib/general/FinalStatement-of-Principles-SRL.pdfs.

136. See e.g. Maranda v. Richer, [2003] 3 S.C.R. 193 at para. 40, where Justice Deschamps explains:

[t]he privilege performs the social function of preserving the quality, freedom and confidentiality of information exchanged between a client and his or her lawyer in the context of a legal consultation. 
Access to justice will be the ethical issue for our generation because it has reached the point where it challenges the fundamental premise of our profession as existing in the public interest. The access to justice crisis exposes the fundamental gap between the promise of the legal profession and its delivery. As the Court has recognized, " $[t]$ he privilege of self-government is granted to professional organizations only in exchange for, and to assist in, protecting the public interest with respect to the services concerned." 137 In their path-breaking study, Lawyers in Canada, which the Supreme Court was quoting, David Stager and Harry Arthurs listed "access to professional services, by all members of the public in need of services" as the first element of the obligation of the legal profession. ${ }^{138}$ When access to a lawyer is out of reach to a large segment of the public, it becomes harder to justify that self-regulation is "in the public interest." It may be in the interest of those that can afford the services of a lawyer and in the interest of the legal profession, but if law has largely become a service industry to a new aristocracy composed of corporations, governments, and wealthy individuals, claims to be in the public interest become much easier to challenge.

Along these lines, the second area of prospective inquiry involves what might be considered the grundnorm of the Canadian legal profession: selfregulation. ${ }^{139}$ Over the past decade, the bar has been engaged in a sustained effort to defend itself from possible government encroachment through a combination of zealous litigation and more modest public advocacy. ${ }^{140}$ Much of the existing case for self-regulation of the legal profession is built on assumptions about the profession that have been increasingly called into

It enables all individuals to participate in sociery with the benefit of the information and advice needed in order to exercise their rights. It is closely associated with access to justice.

137. Stager \& Arthurs, Lawyers in Canada, supra nore 87 at 31.

138. Bryan Williams, "Abuse of power by self-governing bodies" in Law Society of Upper Canada Special Lectures (Toronto: IrwinLaw, 1979) 345.

139. For efforts in this respect see William H. Hurlburt, The Self-Regulation of the Legal Profession in Canada and in England and Wales (Edmonton: Law Society of Alberta, 2000). Much of the work of Harry Arthurs involves the sustained criticism of self-regulation. See especially Arthurs, "The Dead Parrot," supra note 87. Similarly, much of Wesley Pue's work has criticized aspects of self-regulation. See e.g. Pue, "Becoming 'Ethical," supra note 6; and Pue, "In Pursuit of Better Myth," supra note 88.

140. Supra note 94. See also Paul Douglas Paton, In the Public Interest: Threats to Self-Regulation of the Legal Profession in Ontario (S.J.D. Thesis, Stanford Law School, 1998-2006) [unpublished]. 
question over the past. few decades. ${ }^{141}$ As some of these assumptions are -weakened or discredited, and as conceptions of the lawyer's role change; articulating new bases for self-regulation becomes necessary. In addition, while Graham has applied economic analysis to how lawyers behave as individuals, ${ }^{142}$ we have not seen an attempt at an empirical analysis of self-regulation of lawyers in Canada. ${ }^{143}$ In the words of the Competition Bureau of Canada, regulatory decisions must be evaluated "through a balanced, evidence-based assessment, taking into account the numerous channels through which regulation can be beneficial or harmful to consumers." ${ }^{144}$ History and tradition cannot substitute for a searching inquiry. ${ }^{145}$

A third important collective ethical issue is diversity, broadly conceived. It has been fifteen years since the publication of Bertha Wilson's landmark report, Touchstones for Change: Equality, Diversity and Accountability. ${ }^{146}$ Much has been accomplished-women and racialized minorities are now members of law schools and bar associations generally proportionate to their numbers in the general population-but significant challenges remain. While there is less overt discrimination, in many cases the situs of discrimination have simply moved. In

141. See e.g. Pue, "In Pursuit of Better Myth," supra note 88.

142. See supra note 95.

143. Competition Bureau, Self-Regulated Professions, supra note 67, could have provided such an opportunity but the report accepted self-regulation of the legal profession as a given. For an inquiry into the general issue of self-regulation see Andrew Green \& Roy Hrab, "SelfRegulation and the Protection of the Public Interest" (Research Paper no. 26, Prepared for the Panel of the Role of the Government in Ontario, June 2003), online: University of Toronto <http://www.law-lib.utoronto.ca/investing/reports/rp26.pdf $>$. Findings included that self-regulation required some check on self-interested behaviour and that the public's power to check self-regulation has its limits. For economic analyses of different aspects of the regulation of lawyers in Canada, see Michael Trebilcock \& Lilla Csorgo, "Multi-Disciplinary Professional Practices: A Consumer Welfare Perspective" (2001) 24 Dal. L.J. 1 [Trebilcock \& Csorgo, "Multi-Disciplinary Professional Practices"]; Michael Trebilcock, "Regulating Legal Competence" (2001) 34 Can. Bus. L.J. 444 [Trebilcock, "Regulating Legal Competence"]; and Gillian Hadfield, "The Price of Law: How the Market for Lawyers Distorts the Justice System" (2000) 98 Mich. L. Rev. 953 [Hadfield, “The Price of Law”].

144. Competition Bureau, Self-Regulated Professions, ibid. at viii.

145. Thanks to Alice Woolley for discussing the issues in this paragraph, among many others.

146. Bertha Wilson, Touchstones for Change: Equality, Diversity and Accountability (Ottawa: Canadian Bar Association, 1993). See also Elizabeth Sheehy \& Sheila McIntyre, Calling for Change: Women, Law, and the Legal Profession (Ottawa: University of Ottawa Press, 2006). 
the case of women in the legal profession, discrimination has been transferred from entry to law schools and law firms to treatment and retention in the profession. In recognition of the severity of the issue, the LSUC struck a Working Group on the Retention of Women in Private Practice and issued a consultation paper in February 2008. ${ }^{147}$ At a conference at the University of Toronto in May 2007 on Gender and Diversity in the Law, one of the panelists spoke about the phenomenon of "the New Closet." in which women keep their families and family status hidden in order to avoid adverse job consequences. ${ }^{148}$ The link between gender and other grounds for discrimination and legal ethics is overt, and it is now explicitly recognized in ethical codes. ${ }^{149}$ Further, the broader link between issues of diversity, professionalism, and legal ethics has been explored by Constanice Backhouse ${ }^{150}$ and Fiona Kay. ${ }^{151}$ The issue of diversity within the profession is wide and deep, with serious ethical ramifications for the profession and the legal system. As with access to justice, it

147. See Law Society of Upper Canada, Report for the Retention of Women in Private Practice Working Group (21 February 2008), online: <http://www.lsuc.on.ca/latest-news/a/ hottopics/retention-of-women-in-private-practice-working-group/s:

148. See comments by Darlene Johnston, "Identifying the Landscape: The challenges confronting women and equity-seeking groups in the legal profession" (A Summit on Diversity in the Law: Moving Forward as a Profession, presented at the Faculty of Law, University of Toronto, 1 May 2007), online: <http:/www.law.utoronto.ca/visitors_content.asp? itemPath $=5 / 7 / 3 / 0 / 0 \&$ contentId $=1506>$ [A Summit on Diversity in the Law]. This phenomenon was reflected in a neologism reported in the New York Times and reprinted by the The Globe and Mail: "maternal profiling, n. Employment discrimination against a woman who has, or will have, children. The term has been popularized by members of MomsRising, a group promoting the rights of mothers in the workplace." See also Grant Barrett, "Of lolcats, mobisodes and gorno: a look at some of the words that went mainstream this year" The Globe and Mail (28 December 2007) A2.

149. See e.g. CBA, Code of Professional Conduct, supra note 12, c. XX (Non-Discrimination); LSUC Rules, supra note 39, r. 5.03 (Sexual Harassment), r. 5.04 (Discrimination); Law Society of British Columbia, Professional Conduct Handbook, supra note 39, c. 2, r. 3 (Discrimination); Law Society of Alberta, Code of Professional Conduct, supra note 22, c. 1, r. 9 (discrimination), r. 10 (sexual harassment); and Nova Scotia Barristers' Society, Legal Ethics Handbook, supra note 39, c. 24 (Discrimination).

150. See Constance Backhouse, "Gender and Race in the Construction of 'Legal Professionalism," supra note 10.

151. See Fiona M. Kay, "Integrity in a Changing Profession: Issues of Diversity and Inclusion" (Paper presented at the Fifth Colloquium on the Legal Profession, Faculty of Law, Queen's University, 28 November 2005), online: <h九p://www.lsuc.on.ca/media/kaydiversityintegrity.pdfs. 
goes to the heart of the legitimacy of the legal profession and the legal system. Michael Tulloch of the Ontario Court of Justice explained that we live in a multi-cultural, multi-ethnic, and multi-racial society, and every segment of our society should be represented in the composition of our law schools and law firms; if this diversity is not represented, we risk a "crisis of legitimacy within the legal profession and correspondingly within the administration of justice." 152 Former Governor General Adrienne Clarkson has expressed similar concerns about whether the legal profession is serving "the new Canada." ${ }^{\text {"153 }} \mathrm{On}$ a micro-ethical level, we also need to start thinking more about the lawyer's ethical responsibilities and challenges in dealing with an increasingly diverse client population in Canadian society. ${ }^{154}$ Issues of diversity, broadly conceived, will continue to attract attention, scrutiny, and, hopefully, more scholarship.

A final macro-ethical challenge that also has micro-ethical implications is the impact of globalization on the legal profession and the practice of law. We have already seen how lawyer mobility has made conflicts of interest the top ethical priority for the profession over the past decade. Issues such as conflicts, ${ }^{155}$ outsourcing legal work, ${ }^{156}$ dealing with repressive foreign governments, ${ }^{157}$ and the ethical jurisdiction over lawyers' conduct abroad ${ }^{158}$ will take on increased importance in the future.

152. A Summit on Diversity in the Law, supra note 148. (Comments at approximately 50-51 minutes into the web cast).

153. See Her Excellency the Right Honourable Adrienne Clarkson, "Speech on the Occasion of an Honorary Doctorate of Laws Degree from The Law Society of Upper Canada" (27 February 2003), online: Governor General of Canada <http://www.gg.ca/media/doc.asp? lang=e\&DocID=1091>.

154. See articles by Voydovic, supra note 101.

155. See e.g. Nancy J. Moore, "Regulating Law Firm Conflicts in the $21^{\text {st }}$ Century: Implications of the Globalization of Legal Services and the Growth of the "Mega Firm'" (2005) 18 Geo. J. Legal Ethics 521.

156. See e.g. Alison M. Kadzik, "The Current Trend to Outsource Legal Work Abroad and the Ethical Issues Related to Such Practices" (2006) 19 Geo. J. Legal Ethics 731.

157. See James Heffernan, “An American in Beijing: An Attorney's Ethical Considerations Abroad with a Client Doing Business with a Repressive Government" (2006) 19 Geo. J. Legal Ethics 721.

158. See e.g. Law Society of Alberta, Code of Professional Conduct, supra note 22, Preface (“A member of the Law Sociery remains subject to this Code no matter where the member practices law"); Jamie Y. Whitaker, "Remedying Ethical Conflicts in a Global Legal Market" 
Moving from macro-ethical issues to micro-ones, we need to take seriously Allan Hutchinson's point about lawyering in a fragmented society. ${ }^{159}$ Neither the legal.profession nor the clientele that it serves is monolithic. More work needs to be done to analyze the specific issues that lawyers face in different practice contexts: government lawyers, ${ }^{160}$ Crown prosecutors, corporate lawyers (both in-house and external counsel), ${ }^{161}$ family lawyers, immigration lawyers, and others. The model here should be the excellent work on criminal defence practice that has dominated the field of legal ethics and has had the effect of creating a leading paradigm for Canadian legal ethics based on the criminal justice system. ${ }^{162}$ Canadian legal ethics needs to examine wherher issues such as confidentiality and conflicts of interest are really rules of general application across practice areas or whether a more contextual application is in order.

In the introduction, I defined legal ethics as encompassing all of the actors in the legal system: lawyers, judges, clients, self-represented litigants, witnesses, jurors, court administrators, mediators, arbitrators, the media, and others who provide legal services like notaries, immigration consultants, Aboriginal caseworkers, and paralegals. Even the ethical analysis of law professors, inside as well as outside the classroom, should not escape

(2006) 19 Geo. J. Legal Ethics 1079. See also Chi Carmody, "Talisman Energy, Sudan and Corporate Social Responsibility" (2000) 38 Can. Y.B. Int'l Law 237.

159. See Hutchinson, Legal Ethics, supra note 3 at 37-41.

160. For some beginnings in this area see Allan C. Hutchinson, "In the Public Interest': The Responsibilities and Rights of Government Lawyers" (2008) 46 Osgoode Hall L.J. 105; Deborah MacNair, "In the Service of the Crown: Are Ethical Obligations Different for Government Counsel?" (2005) 84 Can. Bar Rev. 501; and Deborah MacNair, "The Role of the Federal Public Sector Lawyer: From Polyester to Silk" (2001) 50 U.N.B.L.J. 125.

161. See e.g. Philip Anisman, "Regulation of Lawyers by Securities Commissions: Sarbanes-Oxley in Canada," Policy Comment (Toronto: Capital Markets Institute, 2003), online: <http://www.rotman.utoronto.ca/cmi/news/LSUCpaper.pdfs.

162. The sources are too numerous to mention but references contained in Proulx \& Layton, supra note 22 are a good start. In addition, many issues are canvassed in Edward L. Greenspan \& George Jonas, Greenspan: The Case for the Defence (Toronto: Macmillan, 1987); Edward L. Greenspan, ed., Counsel for the Defence: The Bernard Cohn Memorial Lectures in Criminal Law (Toronto: Irwin Law, 2005). 
scrutiny. ${ }^{163}$ Ethical inquiries of legal academics have tended to focus on lawyers; to the exclusion of most other actors in the legal system. The subfield of judicial ethics is even more barren than that of legal ethics in Canada, with minimal first or second wave materials. The scholarly treatment of the rest of the actors in the legal system diminishes from there. To the extent that they are recognized, it is usually done in terms of the objects of lawyers' or judges' interactions rather than as independent participants in the justice system.

Connected to the access to justice agenda, there are a number of civil justice issues that have generally not been adequately addressed by Canadian legal ethics scholars. Class actions are a relatively new and still controversial phenomenon in Canada ${ }^{164}$ and are either an ethical minefield or goldmine, depending on one's perspective. ${ }^{165}$ Regardless, class actions are an under-

163. For a recent provocative article in this respect see William H. Simon, "The Market for Bad Legal Advice: Academic Professional Responsibility Consulting as an Example" (2008) 60 Stan. L. Rev. [forthcoming], online: Social Science Research Network <htrp://ssrn.com/abstract=1025984>.

164. A recent profile of class action king Tony Merchant raises numerous ethical issues. See Timothy Taylor, "The Merchant of Menace," supra note 34. It claims that Merchant billed 5,300 hours in a recent year ("many in the legal community are frankly amazed that anyone could have billed" that amount (at 29)) and notes that Merchant's firm placed a Yellow Pages ad for "the seemingly impartial 'Lawyer Referral Service' which in fact" links directly to one of the firm's lawyers (at 30). The article also raises some of the ethical issues with national and international class actions. Merchant's firm also engages in domain name relaying, a practice whereby one erroneously typed webpage (e.g. 〈http://www.mcdonaldsclassaction.com>) links to Merchant's webpage (<http://www.merchantlaw.com>) instead of the webpage that the user is actually seeking (<http://www.mcdonaldscontestclassaction.com> which links to the homepage of the law firm actually representing the plaintiff class, Toronto's Paliare Roland at <http://www.paliareroland.com/mcdonalds.asp>).

165. For an example of American scholarship on the subject see David J. Kahne, "Curbing the Abuser, Not the Abuse: A Call for Greater Professional Accountability and Stricter Ethical Guidelines for Class Action Lawyers" (2006) 19 Geo. J. Legal Ethics 741. The Georgetown Journal of Legal Ethics devoted an entire issue to a symposium on ethical issues in class actions ((2005) 18 Geo. J. Legal Ethics 1161-1476). Some of the tidles include "The Use of . Coupon Compensation and Other Non-Pecuniary Redress"; "Tools for Ensuring that Settlements Are "Fair, Reasonable, and Adequate"; "Special Ethics Concerns in Class Action Litigation"; "Do You Really Want Me to Know My Rights? The Ethics Behind Due Process in Class Action Notice Is More Than Just Plain Language: A Desire to Actually Inform"; and "The Ethical Imperative of a Lodestar Cross-Check: Judicial Misgivings About 'Reasonable Percentage' Fees in Common Fund Cases." 
developed area of legal ethics scholarship. ${ }^{166}$ Similarly, there is much ethical exploration to be done about contingency fees and self-represented litigants, to name just a few issues.

Various social phenomena affect the practice of law and create ethical challenges for lawyers. Technology, for example, has a significant impact on various aspects of the practice, from discovery, to client service, to confidentiality, to lawyer advertising, and to social networking sites and blogging. ${ }^{167}$ While the legal profession and legal scholars have become more aware of diversity, we have not yet begun to grapple with issues that we face as a profession in an aging society, both in terms of issues that aging lawyers will face as well as issues that lawyers face in dealing with older clients. These include issues of competency (to practice law in the case of lawyers and to give instructions in the case of clients), and cognitive and physical disability. ${ }^{168}$

On particular issues, we have not begun to critically examine the role of lawyers and law firms in the Conrad Black and Hollinger Inc. meltdown. The work of one of Canada's most esteemed law firms, Torys, was centre stage during the trial of Conrad Black and his associates, which included two lawyers, one of whom, Peter Atkinson, is still a member of the Ontario bar but likely to face disbarment due to his criminal conviction for fraud. And what of Torys and its lawyers? Are they being investigated by the Law

166. For exceptions in this respect see Benjamin Alarie, "Rethinking the Approval of Class Counsel's Fees in Ontario Class Actions" (2007) 4 Can. Class Action Rev. 15; Shaun Finn, "Summoning Leviathan: A Critical Analysis of Class Action Theory and the Ethics of Group Litigation" (2007) 4 Can. Class Action Rev. 199; Michael P.A. Carabash, "Ethical Conduct for Class Counsel in Ontario" (2006) 3 Can. Class Action Rev. 617; J.J. Camp, "Avoiding Pitfalls and Potential Conflicts in Negotiating Class Counsel Fees and Obtaining Court Approval" (2006) 3 Can. Class Action Rev. 277; Kevin Rusli, "The Collusion Crisis: Problems and Proposals" (2005) 2 Can. Class Action Rev. 249; and Cara Faith Zweibel, "Settling for Less? Problems and Proposals in the Settlement of Class Actions" (2004) 1 Can. Class Action Rev. 165. It is notable that all of these articles are contained in a specialized journal on class actions rather than in general law reviews. See also Craig Jones, Theory of Class Actions (Toronto: Irwin Law, 2003) at 91-95, 143-50 (collusion), 240-46 (counsel fees).

167. See generally Melissa Blades \& Sarah Vermylen, "Virtual Ethics for a New Age: The Internet and the Ethical Lawyer" (2004) 17 Geo. J. Legal Ethics 637; Christopher Hurld, "Untangling the Wicked Web: The Marketing of Legal Services on the Internet and the Model Rules" (2004) 17 Geo. J. Legal Ethics 827.

168. See Robert Dowers, "Duties Invoked Under the Model Rules of Professional Conduct by a Mentally Impaired Lawyer" (2006) 19 Geo. J. Legal Ethics 681. 
Society? Should they be? ${ }^{169}$ The Black case highlights many ethical issues and is ripe for serious critical commentary.

Finally, on the issue of method, there is a dearth of empirical, interdisciplinary, and comparative research on the legal profession in Canada. In the 1990s, a team at the University of Western Ontario's Faculty of Law led by Margaret Ann Wilkinson and Peter Mercer undertook an excellent study of lawyers in Ontario, but such work has been rare. ${ }^{170}$ Similarly, interdisciplinary approaches are rarely brought to bear on legal ethics. The exception of Randal Graham's provocative economic analysis of legal ethics has already been mentioned. ${ }^{171}$ On comparisons, the links between the Canadian legal professions and those of America and Britain are well established, and comparison of aspects of these systems to ours would provide fruitful inquiry. In acknowledgement of the needs in this area, the Ontario Law Deans have promoted the idea of creating a research institution, modeled on the highly respected American Foundation, to undertake high quality, interdisciplinary research on the legal profession and.on legal ethics. ${ }^{172}$ As Dean Bruce Elman of

169. See Jim Middlemiss, “Torys Teflon coat deflects hazards; Minimal fallout from Hollinger legal wrangles" National Post (12 December 2007) FP11.

170. The University of Western Ontario's major research initiative was entitled "Professionalism or Profit: The Changing Nature of Legal Ethics" and had both empirical and theoretical aspects. See Peter Mercer, Margaret Ann Wilkinson \& Terra Strong, "The Practice of Ethical Precepts: Dissecting Decision-Making by Lawyers" (1996) 9 Can. J.L. \& Juris. 141; and articles by Wilkinson et al. cited in supra note 88 . Other notable exceptions include the work of sociologists Fiona Kay of Queen's University and Joan Brockman of Simon Fraser University, who have been embarked on this type of research for more than a decade; see supra note 104 and 105. Stager and Arthurs' landmark book on Canadian lawyers is now almost two decades old and in need of replacement. See Stager \& Arthurs, Lawyers in Canada, supra note 87 . On the relationship between law and psychiatry see McGillivary, "A moral vacuity," supra note 89.

171. Other notable Canadian law and economic analyses of issues of legal ethics include Trebilcock \& Csorgo, "Multi-Disciplinary Professional Practices," supra note 142; Trebilcock, "Regulating Legal Competence," supra note 142; Hadfield, "The Price of Law," supra note 142; Ronald J. Daniels, "The Law Firm as an Efficient Community" (1991) 37 McGill L.J. 801; and Robert G. Evans \& Michael J. Trebilcock, eds., Lawyers and the Consumer Interest: Regulating the Market for Legal Services (Toronto: Butterworths, 1982).

172. See Bruce P. Elman, "Creating a Culture of Professional Responsibility and Ethics: A Leadership Role for Law Schools" (Paper presented at the Eighth Colloquium on the Legal Profession: The Challenges of Leadership, University of Western Ontario, 25 May 2007), online: <http://www.lsuc.on.ca/media/eighth_colloquium_professional_responsibility_ethics.pdfs. 
Windsor has stated, "[o]ne thing is clear: we know very little about the legal profession in Ontario." ${ }^{\prime 13}$ Elman has suggested that empirical research be undertaken to examine the correlation (if any) between teaching legal ethics and subsequent discipline problems among lawyers. Empirical research is also necessary to test some of our assumptions about the legal profession-about things that we claim to know, but remain completely matters of faith in the legal profession-such as the function of the lawyer's duty of confidentiality and solicitor-client privilege in promoting full and frank disclosure between lawyers and clients. ${ }^{174} \mathrm{~A}$ research institution dedicated to studying the legal profession would be a welcome addition to Canadian legal ethics and is perhaps the most pressing item on the agenda for Canadian legal ethics in the twenty-first century.

\section{CONCLUSION}

In this article, I introduced the concept of multiple accounts of legal ethics in Canada and argued that significant disparities exist between them. In reviewing the major events in Canadian legal ethics over the past decade, largely through the lens of the public account and of the legal profession's account, I endeavoured to show some of the gaps between them, and between these accounts and the scholarly account of Canadian legal ethics. Despite the existence of many high-profile ethical scandals within the profession over the last decade, none has succeeded in capturing the public agenda and driving change within the profession. Perhaps somewhat surprisingly, the level of trust in lawyers remained constant over the decade and, in fact, increased during the period in which there was arguably the most negative attention focused on lawyers' actions. There is no question that such events have had an effect within the legal profession and the academy, and have helped to motivate many significant changes in recent years. Yet the fact remains that we have precious little empirical data about what actually goes on in the practice of law; the Ontario Law Deans' proposal for the creation of a high-quality research institution to conduct such empirical and interdisciplinary work is timely. Legal ethics has grown as an academic discipline in terms of both scholarship and

173. Ibid. at 20 .

174. This is an issue that I take up in a forthcoming paper, Adam Dodek, "Theoretical Foundations of Solicitor-Client Privilege" [forthcoming in 2008]. 
course offerings, as reflected by a group of New Legal Ethics Scholars who are beginning to tackle some of these issues. However, with these developments, we can also recognize that the ethical terrain yet to be explored is vast. Canadian legal ethics now looks very different than it did twenty-five or even ten years ago. At last, Canadian legal ethics appears ready to tackle the issues before it in the twenty-first century. 
